\title{
European Development Banks and the Political Cycle
}

\begin{abstract}
This paper investigates whether the lending activity of European development banks is affected by opportunistic political behavior, by looking at the change in loans extended by these entities in election years. The empirical analysis leverages on a unique manually collected dataset that includes all the development banks headquartered in Europe, for the period 2002-2015.

A comparison with the rest of the European banking system reveals that while the political view of development banks cannot be supported as a general rule, it finds empirical evidence in flawed democracies, where large development banks actually tend to increase their lending activity in election years.
\end{abstract}

\section{Keywords}

Development Banking; Ownership; Lending; Political Interference; Political Business Cycle

\section{JEL codes}

O16; L32; G21; D72; G28 


\section{Introduction}

The aim of this paper is to investigate whether the lending activity of development banks headquartered in Europe is affected by political influences. The topic is of utmost relevance given the strategic role that contemporary development banks are playing in Europe, coupled with the ancestral fear that these public subjects may distort the allocation of resources.

Development banks are "legal entities carrying out financial activities on a professional basis which are given a mandate by a member state or a member state's entity at central, regional or local level, to carry out development or promotional activities" (European Commission, 2015b). While there is a general consensus on the role of development banks in mitigating market failures (De Olloqui et al., 2013; de Luna-Martinez and Vicente, 2012; Foray et al., 2012; Yeyati et al., 2004; Gutierrez et al., 2011), the issue traditionally raised is whether this positive contribution is more than offset by misallocation of resources and destruction of value due to political interference and inefficiencies.

As a matter of fact, according to the so-called political view of government bank ownership, perverse effects due to political motivations may prevail on the desirable contribution of government ownership to promote socially valuable projects (Hart et al., 1997; Kornai, 1979; La Porta et al., 2002; Shleifer and Vishny, 1994, 1997). While state-owned, non-financial enterprises can be used by politicians to provide jobs and direct resources to friends and supporters, state-owned banks can be induced by the incumbent policymakers to finance favored enterprises (Sapienza, 2004; La Porta et al., 2002) and, more generally, to increase their lending activity during election periods in order to seek and retain the favor of the voters (Dinc, 2005). 
This may result in misallocation of funding motivated by two main hypotheses: the "soft-budget constraints hypothesis" and the "rent-seeking hypothesis." The "softbudget constraints hypothesis" (Kornai, 1979; Lin and Tan, 1999) suggests that abundant and lenient capital from the state increase the likelihood that state-owned banks may approve bad investments and use public funds to bail out companies that would otherwise fail. Slightly differently, the "rent-seeking hypothesis" (Ades and Di Tella, 1997; Claessens et al. 2008) argues that funds are channeled to politically connected industrialists, who indeed receive substantially preferential treatment in terms of interest rates and access to credit even though they do not need subsidized capital. In both cases, firms will obtain capital for reasons other than the inherent financial potential of their own project, resulting in economically inefficient uses of public resources (Dinc, 2005; Micco et al., 2007; Lazzarini et al., 2015; Khwaja and Mian, 2005). It is just to prevent these negative side effects and the misallocation of resources that the European Commission itself underlines the need for development banks to adopt proper policies and best practices (European Commission, 2015b; European Parliament, 2016).

Extant empirical literature has already analyzed the lending behavior of state-owned banks with the aim of assessing whether their activity is influenced by political considerations, with results that generally support the political view of government bank ownership. In particular, Sapienza (2004) finds that the lending behavior of stateowned banks in Italy is affected by the electoral results of the party affiliated with the banks' top executives. Khwaja and Mian (2005) observe that state-owned banks in Pakistan tend to lend more to firms with politically connected directors. Dinc (2005) empirically analyzes government-owned banks in 43 countries across the world and finds that the lending activity within developing countries is influenced by politics, 
while this is not the case in developed economies. Similar results are shown in Micco et al. (2007), where the authors observe that state-owned banks located in developing countries increase loans during election years, while state-owned banks in developed countries do not. ${ }^{1}$

However, all these studies focus on government-owned financial institutions, while development banks are rather a different type of financial institution (although they are also owned by the government (see Section 2.1)), with consequences in terms of political distortion that are largely unexplored as of yet.

So far, the only empirical paper directly testing the political view on development banks is Lazzarini et al. (2015), who concentrate on the Brasilian Development Bank (BNDES) and analyze the performances of firms receiving its financial support. While confirming that political influences matter, they find that the BNDES does not appear to systematically channel funds to underperforming firms, although targets do not display any consequent beneficial effect in terms of performance and investment.

We adopt a distinctive perspective from Lazzarini et al. (2015), since we focus on European countries (including both developed countries and economies in transition) and we investigate how the lending activity of development banks changes around elections compared to other financial institutions. The empirical analysis leverages on a unique, manually collected dataset that includes all the development banks

\footnotetext{
${ }^{1}$ There is also a larger body of empirical literature - beyond the scope of our paper - that analyzes the relationship between ownership, bank performance and financial development (among them: La Porta et al., 2002; Barth et al., 1999; Beck and Levine, 2002; Berger et al., 2005; Yeyati et al., 2007; Cornett et al., 2010; Chakravarty and Williams, 2006; Altunbas and Marques, 2008; Yildirim and Philippatos, 2007; Iannotta et al., 2007).
} 
headquartered in Europe. Financial information is benchmarked with a selected sample of more than 4,200 financial institutions for the period 2002-2015.

Results show that the political view of development banks is not supported as a general rule. In particular, in full democracies no empirical evidence is found of opportunistic manipulation of development banks' activity for electoral purposes. By contrast, there is evidence of politically motivated lending from development banks in European countries with weaker political institutions, in the form of increased lending in election years relative to the rest of the banking system.

A battery of robustness tests confirms our results. The adoption of alternative measures for the main variables of our interest and the recourse to alternative econometric approaches produce very consistent findings.

The remainder of the paper is organized as follows. Section 2 illustrates the specificities of development banks and introduces the hypotheses. Section 3 describes our sample and the dataset. Section 4 defines the methodology. Section 5 discusses results and Section 6 presents a battery of robustness checks. Section 7 concludes.

\section{The framework}

\subsection{Development banks}

Development banks are public sector or government-invested legal entities with an explicit policy mandate to promote socio-economic goals in a region, sector or specific market segment (de Luna-Martinez and Vicente, 2012). ${ }^{2}$

\footnotetext{
${ }^{2}$ In the Introduction, we used the more recent definition from the European Commission. Alternative definitions of development banks, also referred to as development financial institutions, state investment banks, promotional banks include: "institutions to promote and finance enterprise in the private sector" (Diamond, 1957); “government-sponsored financial institutions concerned primarily with the provision
} 
Existing empirical literature typically considers all public financial institutions as though they belong to the same type. However, development banks have specific goals and market failures they set out to redress that deserve specific attention, and they are becoming increasingly important in light of their growing relevance in Europe.

Development banks typically fund projects with high risk, which is usually the case of high-tech or new industries, start-up and R\&D investments, by providing direct or indirect loans, credit guarantees and equity tools such as venture capital, private equity, seed capital financing or mezzanine financing to enable firms to access the capital necessary for growth (Musacchio et al., 2017; Mazzuccato and Penna, 2016; Bleda and Del Rio, 2013). They also provide long-term "patient" capital to promote strategic investments for economic development (e.g. infrastructure projects, export, housing, etc.) or for socially challenging projects (e.g. climate finance, renewable and environmental-friendly energy, food security initiatives) (Foray et al., 2012; Eslava and Freixas, 2016; De Olloqui, 2013; Yeyati et al., 2007). In addition, development banks play a counter-cyclical role in time of crises, by sustaining growth and employment during periods of recession, when banks typically disintermediate their credit activity because of deteriorating asset quality, capital shortages, deleveraging and higher risk aversion (Gutierrez et al., 2011; Yeyati et al., 2007; Luna-Martinez and Vicente, 2012).

More recently, in the aftermath of the economic and financial global crisis, development banks have been called on by European policy makers to share the management of EU financial instruments and to play a primary role in restructuring the

\footnotetext{
of long-term capital to industry" (De Aghion, 1999); "financial institutions that are primarily concerned with offering long-term capital finance to projects that are deemed to generate positive externalities and hence would be underfinanced by private creditors" (Yeyati et al., 2004).
} 
economy, channeling leveraged funds into the market, boosting innovation, supporting socio-economic and environmental challenges, and implementing financial instruments and programs set up to reverse the low level of investment by EU firms, in particular start-ups and SMEs (European Commission, 2014, 2015a; Mertens and Thiemann, 2019; Clifton, Diaz-Fuente and Gomez, 2018). Accordingly, in recent years development banks have significantly increased their assets, co-financed a rising number of projects and investment platforms, fostered the growth of venture capital across Europe and enlarged the business volume in resource efficiency, digital infrastructure and innovation. ${ }^{3}$

On the whole, development banks have specific industry- and firm-level targets, are involved in complex and large-scale projects and present clear differences in terms of business models and types of activity compared to other types of public financial institutions, such as state-owned commercial banks like Crédits municipaux in France, cajas de ahorros in Spain, Landesbanken and Sparkassen in Germany, cantonal banks in Switzerland and Regionalbanken "Нypo" in Austria.

Indeed, state-owned commercial banks, like private commercial banks, are primarily involved in retail banking activities, such as bank accounts, payment services, insurance products and loans to households and enterprises, and their liabilities are mainly represented by retail deposits. By contrast, development banks are not allowed to directly take retail deposits and typically depend on market financing, budget transfers from the government and European programs. Historically, state-owned commercial banks have been established in the form of cooperative or saving banks with the mission

\footnotetext{
${ }^{3}$ See Mertens and Thiemann, 2019; KfW et al., 2016; Bertoni and Tykvová, 2015; and annual reports from development banks such as the European Investment Bank, Kreditanstalt fuer Wiederaufbau KfW, Caisse des Depots et Consignations, Istituto de Credito Oficial, Cassa Depositi e Prestiti.
} 
to supply retail banking services to the masses and to favor their financial inclusion both geographically (providing access to financial services in remote areas) and socially (providing basic banking services to all, regardless of their financial attractiveness). Nowadays most of them are joint-stock companies, because of changes in regulation and/or privatization, and, in some countries, they are no longer government-owned.

So far, only a few papers acknowledge the extant differences between development banks and state-owned banks (Bacchiocchi et al., 2017; de Luna-Martinez and Vicente, 2012; Lazzarini et al., 2015; Yeyati et al., 2004). Schmit et al. (2011) provide a rationale for a classification of state-owned banks based on an extensive analysis of the missions and roles of public financial institutions and clearly highlight differences between development banks and other public financial institutions.

More generally, little is known about development banks, and apart from theoretical contributions discussing their growing importance and role in Europe, empirical studies on their firm-level characteristics and on the impact of their activity are scant and mainly focused on single multi-lateral institutions, such as the European Investment Bank (Clifton et al., 2014; Tuijnman, 2009; Griffith-Jones and Tyson, 2013).

\subsection{Our hypotheses}

The above-mentioned specificities of development banks may have consequences in terms of potential political distortion that are largely unexplored as of yet. Specifically, some factors may reduce the pressure of politics in the case of development banks and may serve to break the tight meshes that traditionally linked state-owned banks' decisions to politics.

For example, the investment cycle of a development bank is typically much longer compared to the electoral cycle. There is usually a long distance between the decision 
of financing a project, its physical implementation and the consequent financial returns and economic and social benefits (World Bank, 2018). Therefore, the convenience to pursue political objectives through the lending activity of development banks is more indirect and blurred. Besides, development banks interventions are frequently targeted to a priori identified sectors, industries or geographical areas where the financing gap from the private sector is stronger (e.g. new infrastructures and societal challenges that need patient and risky capital; European Commission, 2015b), thus reducing political opportunities to misallocate resources. Finally, development banks also act as catalysts for private finance and means of mobilizing resources and skills and channeling them as investments in the private sector (European Commission, 2018; OECD, 2018). Again, such private co-financing reduces the possibility of politically motivated lending to non-viable projects that would not be co-financed by the private sector.

According to this, if development banks operate within their mandate, there is no reason why their lending activity should differ from the lending activity of other (nondevelopment) banks just in electoral years (except for differences controlled for with other explanatory variables). Therefore, our baseline prediction is that the amount of loans supplied by development banks is not influenced by the electoral cycle:

\section{Hypothesis 1. The electoral cycle does not affect the lending activity of the development banks to a different extent than it does for the rest of the banking system.}

However, we are aware that at least in some countries, the degree of formal and informal influence exerted by the government may actually affect the activity of development banks. In fact, our analysis on the lending behavior of development banks during pre-election periods intersects the existing literature on political business cycles, 
i.e. on political determinants of macroeconomic cycles (Nordhaus, 1975). According to the theory on political business cycles, an opportunistic incumbent policymaker may try to manipulate monetary and fiscal policies in order to induce economic expansions before the elections and, consequently, to influence the voting (and his/her probability of re-election) through economic performance. In this context, the review of Drazen (2000) reports clear evidence of pre-electoral increases in fiscal policy instruments, especially in developing countries. ${ }^{4}$ In particular, several studies suggest that opportunistic pre-electoral manipulation is more likely to materialize in countries with lower degrees of democracy, lower transparency and a weaker institutional set of checks and balances, since the power of the incumbent is less constrained (Schuknecht, 1996; Gonzalez, 1999; Shi and Svensson, 2002).

However, explicit fiscal rules and high debt burdens tend to restrict government spending and the possibility of manipulating fiscal policy to affect election outcomes. In this context, the credit supplied by development banks may offer an alternative tool to boost the economy or support specific borrowers (and projects) just before the next election. If development banks are not sufficiently free from outside control of the central government, their activity may be influenced and used by the executive power in order to help the re-election of the incumbent. Indeed, we may expect that in flawed democracies development banks do not fully operate within their mandates and support short-term political objectives of the incumbent policymaker. This would affect their

\footnotetext{
${ }^{4}$ According to Drazen (2000), the existing literature on political business cycles reveals that explanations based on fiscal policy as a driving force of the political business cycle provide a more convincing story than explanations based on manipulation of the monetary policy. The latter are even less realistic when considering countries where central banks are sufficiently independent from the central government and the monetary policy is not under the direct control of the incumbent policymakers.
} 
lending behavior especially in election years.

Consequently, we want to test whether development banks may play a role in opportunistic pre-electoral manipulation in those countries characterized by weaker political institutions and lower constraints on the executive power. Following this logic, we formulate the following:

\section{Hypothesis 2. Development banks located in countries with flawed democracies are more likely to increase lending in election years relative to the rest of the banking system.}

\section{The data}

\subsection{Bank-level characteristics}

Our empirical analysis begins with an accurate taxonomy of development banks in Europe, since there is not a universally recognized and readily available scheme (or classification) for these financial intermediaries. We start the identification and mapping of European development banks by referring to the banks' classification available within the Orbis Bank Focus database, produced by Bureau van Dijk (BvD). Specifically, the majority of European development banks are identified among those institutions classified as Specialized governmental credit institutions. ${ }^{5}$

Secondly, other development banks are identified thanks to the available information on banks' characteristics and their textual descriptions in Orbis Bank Focus. Lastly, we devoted considerable effort to refining the initial selection of European development

\footnotetext{
${ }^{5}$ Multi-lateral governmental banks, such as the European Investment Bank, are excluded from our empirical analysis because of the questionable identification of electoral years at a supranational level.
} 
banks through manual inspection, online research and a general review of annual reports and publicly available information. ${ }^{6}$

After excluding three development banks that had no financial data available in Orbis Bank Focus, we finally identified 73 development banks, including national development banks (e.g. the German Kreditanstalt fur Wiederaufbau KfW, the Italian Cassa Depositi e Prestiti CDP and the French Caisse des Dépôts et Consignations CDC), and smaller regional promotional banks (e.g. Hamburgische Investitions- und Foerderbank, Institut Catala de Finances, and Banca Mediocredito del Friuli Venezia Giulia Spa), located in 27 European countries.

For the purposes of our study, the lending behavior of development banks is benchmarked with that of a selected sample of non-development banks headquartered in Europe. In particular, we exclude from our benchmark those banks with very specific specializations (e.g. central banks, Islamic banks, securities firms, micro-financing institutions, etc.). We also exclude banks from countries where no development banks have been detected. Finally, when the BvD database reports both consolidated and unconsolidated accounts, we use the consolidated ones. Accordingly, in order to avoid double counting, we exclude from the sample the subsidiaries of those parent companies whose accounts are consolidated. ${ }^{7}$

\footnotetext{
${ }^{6}$ In particular, we also classify as development banks all those institutions that are members of specific European associations such as the European Development Financial Institutions (EDFI), an association of export credit agencies mainly focused on the development of private enterprises in developing and emerging economies with the mandate to foster growth in sustainable business, and the Network of European Financial Institutions for SMEs (NEFI), whose public mission is to facilitate access to finance growth and internationalization of SMEs by offering them financial services and expertise.

${ }^{7}$ Subsidiaries are only excluded when the ownership share is larger than $50 \%$, approximately assuming this as the minimum percentage of ownership that is needed for consolidation.
} 
Financial data are collected from the Orbis Bank Focus database (BvD). Since this dataset is currently restricted to only 3-5 years of data, we retrieve older financial data by accessing BvD Bankscope historic disks. ${ }^{8}$ Notwithstanding available data starting from 1987, our empirical analysis focuses on the time interval 2002-2015 since we have very few available observations before this period. Indeed, available observations increase significantly after 2002, when they are still around 50 percent of the available observations in the most recent years.

Further data cleaning is carried out in order to prevent the analysis from being distorted by unwanted factors. First, we drop the top and bottom $2 \%$ of firm-year observations with respect to the Loans Growth variable (our main dependent variable of the regression model introduced in Section 4) since these observations are likely to be affected by M\&As, de-mergers or other structural (non-operating) changes. We also clean the dataset by eliminating inconsistent information (e.g. negative values for financial items that are expected to be non-negative). Finally, we drop all firm-year observations with missing values for Loans Growth or one of the main control variables in our regression model, i.e. Total Assets (lagged value), Non-Interest Revenues over Total Assets (lagged value) or Shareholders' funds over Total Assets (lagged value). We remain with an unbalanced panel of 40,201 bank-year observations referring to 4,228 banks and 73 development banks.

\footnotetext{
${ }^{8}$ The merging of historical and current financial information from BvD is complicated by the fact that the BvD ID number, by which BvD identifies each bank, may change over time. Therefore, before the merger, we had to replace the old IDs with the most recent ones. By referring to the $B v D I D C h a n g e$ Lookup tool, it is possible to obtain the list of BvD ID changes that involved our sample of banks within the reference period. For a similar merging procedure on Orbis data, see also Kalemli-Ozcan et al. (2015).
} 
Table A.1 of the Appendix presents the descriptive statistics for the main bank characteristics of our interest, comparing development banks with the rest of the banking system. ${ }^{9}$ Data reveal interesting differences between development banks and the other (non-development) banks in our sample. On average, development banks are three times the size in terms of total assets (TA), they have higher capital ratios (CAP) and a lower incidence of the loan portfolio (LOANS), which is mainly due to the weight of their portfolio on equity investments, as suggested by inspection of individual data. Development banks also display a faster annual increase in loans relative to total assets ( $\triangle$ LOANS), despite that the difference is statistically significant only in the subsample of "full democracies." Interestingly, in both the two subsamples, development banks also exhibit a statistically significant lower incidence of operating expenses (OPEX) compared to other financial intermediaries, due, among other things, to the significantly lower number of employees per asset volume and their wholesale business model.

Figure 1 compares the distribution by total assets of development banks and other (non-development) banks. After separating development banks at their median asset size (i.e. about 15.1 EUR thousands, in natural logarithms), we find that the larger development banks (shown darkly shaded in the figure) are placed above the 90th percentile of the distribution referred to non-development banks (dashed line), while the smaller development banks (shown lightly shaded in the figure) are placed between the 22 nd and the 90 th percentile. There are no development banks collocated below the

\footnotetext{
${ }^{9}$ Descriptive statistics are obtained after winsorizing all the financial ratios, since they are shown to vary substantially within our sample. The winsorizing procedure replaces values above the 98th percentile and below the 2nd percentile respectively with the 98th percentile and the 2nd percentile. By contrast, our regressions are estimated without applying this winsorizing procedure, but we finally checked that the main results hold even after winsorizing.
} 
22nd percentile (i.e. about 11.3 EUR thousands, in natural logarithms).

Figure 1 -Distribution of DBs and non-DBs by size

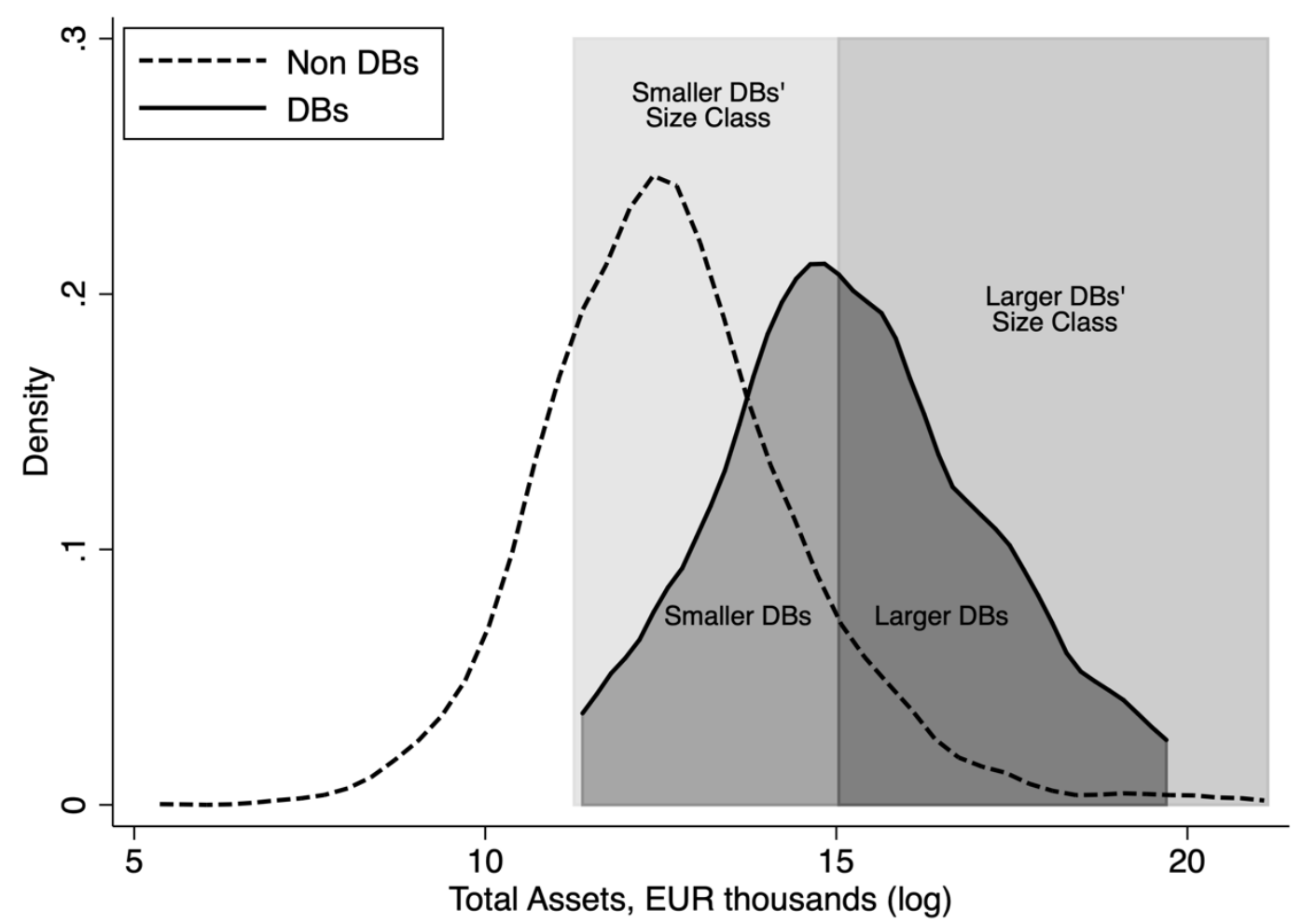

In the event that the coefficients of our model specifications depend on bank size, the different distribution of development banks and non-development banks will bias our estimates. For this reason, in the econometric analysis we also run all the regressions within separate size classes, so that all the coefficients are allowed to vary with asset size. In particular, we consider the following groups: (i) the whole sample includes all the available observations; (ii) the smaller DB's size class includes banks in the percentiles 22-90 by total assets; (iii) the larger DBs' size class includes banks above the 90th percentile. This setting allows to verify if (and how) the estimates are influenced by the relative size of development banks compared to other banks.

\subsection{Democratic development}

In order to consider the institutional characteristics of the different countries in 
which development banks operate, we also collect data on institutional quality at the country level. Specifically, we refer to constitutional democratic development (DEMOC), measured by the Polity IV Project on a zero-to-ten scale, with zero indicating that there is no institutional democracy and 10 indicating "full" democracy. Indeed, in line with Delis et al., (2017), we consider “"democratic development' as a general institutional umbrella that primarily encompasses changes in constitutional characteristics of democracy, such as a system of free elections, the evolution of checks and balances by independent political bodies, and the evolution of civil liberties." In Section 6 we also test the robustness of our main findings when considering specific subcomponents of the DEMOC indicator, such as the Executive Constraints (XCONST), or alternative country indexes, such as the Worldwide Governance Indicators (WGI). ${ }^{10}$

For the purpose of our study, we split the main sample in two macro-areas, based on the "maturity" of democracy in each country. Since most of the European countries in our sample are classified as "full democracies" (DEMOC=10), we compare the lending behavior of development banks and other banks in these countries with their peers in "flawed democracies" (DEMOC < 10). Countries are allowed to move from one group to another according to the annual value of DEMOC. The aforementioned table A.1 shows that in the time interval 2002-2015 development banks report a higher annual $\triangle$ LOANS in both the two subsamples, despite that the difference is statistically significant only in the subsample of "full democracies." The main objective of our study is to examine how this difference is affected by the electoral cycles after controlling for the business cycles.

\footnotetext{
${ }^{10}$ Kaufmann et al (2010).
} 


\subsection{Electoral cycles and business cycles}

Given our specific interest in the lending behavior of development banks over the electoral cycle, we also collect data on electoral years using the Database of Political Institutions 2017 (Cruz et al., 2018). We consider presidential elections in countries with a presidential system and legislative elections otherwise. In line with Dreher and Vaubel $(2004,2009)$, we build a continuous variable, $E L E C T_{c, t}$, that is defined as the share of the year $t$ that falls within the twelve months prior to a national election in country $c .{ }^{11}$ By introducing this measure, we take into account that the time of the year in which the election takes place could be relevant for the timing of an eventual opportunistic behavior of development banks. Indeed, if elections take place early in the calendar year $t$, electoral incentives and politically-motivated lending are likely to realize in year $t-1$.

Finally, we recur to IMF databases in order to collect information on GDP growth, as a proxy for business cycles at the country level. Indeed, we mentioned before that according to the literature on the political business cycle, there may exist a correlation between the electoral cycles and the business cycles. Consequently, without controlling for GDP growth, our analysis on the different behavior of development banks and private banks in a pre-electoral period could be severely distorted by the lack of attention on the contemporaneous effects of the business cycle. ${ }^{12}$ In addition, the

\footnotetext{
${ }^{11}$ Following the example of Dreher and Vaubel (2009), 'if the election took place in February, the index would take the value of 2/12 in that year and 10/12 in the year before'.

${ }^{12}$ Micco et al. (2007) adopt a similar approach in order to analyze the different behavior of foreign and state-owned banks with respect to private domestic banks over both the electoral cycle and the business cycle.
} 
analysis of differential reactions of development banks and private banks to the business cycle is also relevant by itself. Even if it is not the main focus of this paper, it adds a relevant piece of information on potential good features of development banks' activity. Indeed, if the empirical results revealed that the lending of development banks is more resilient than the lending of other banks to the business cycle, this would add an argument in favor of development banks' activity that could potentially compensate for, or even outweigh, the possible inefficiencies due to opportunistic political behavior.

Figure 2 shows the relationship between GDP growth ( $\Delta$ GDP) and the change in loans ( $\triangle$ LOANS) for each country-year. Specifically, we measure the aggregate measure of $\triangle \mathrm{LOANS}$ for each country-year as the weighted average of the banks belonging to each country, with weights assigned according to total assets at the beginning of each year (end of previous year). The prediction lines and confidence intervals referring to the entire banking system reveal, as is reasonable to expect, a positive relationship between $\triangle \mathrm{GDP}$ and $\triangle \mathrm{LOANS}$. However, the different slope of the prediction lines suggests counter-cyclical behavior of European development banks, with less sustained loan growth in boom years but greater resilience during downturns, when credit supply from other lenders typically slows down. This evidence offers a positive picture of the behavior of the development banks in terms of their beneficial support to the real economy and confirms that the omission of the $\Delta$ GDP variable would severely affect our next analysis on the different lending behavior of development banks over the electoral cycle relative to other banks. 
Figure $2-\Delta$ LOANS and $\Delta$ GDP by Country-Year

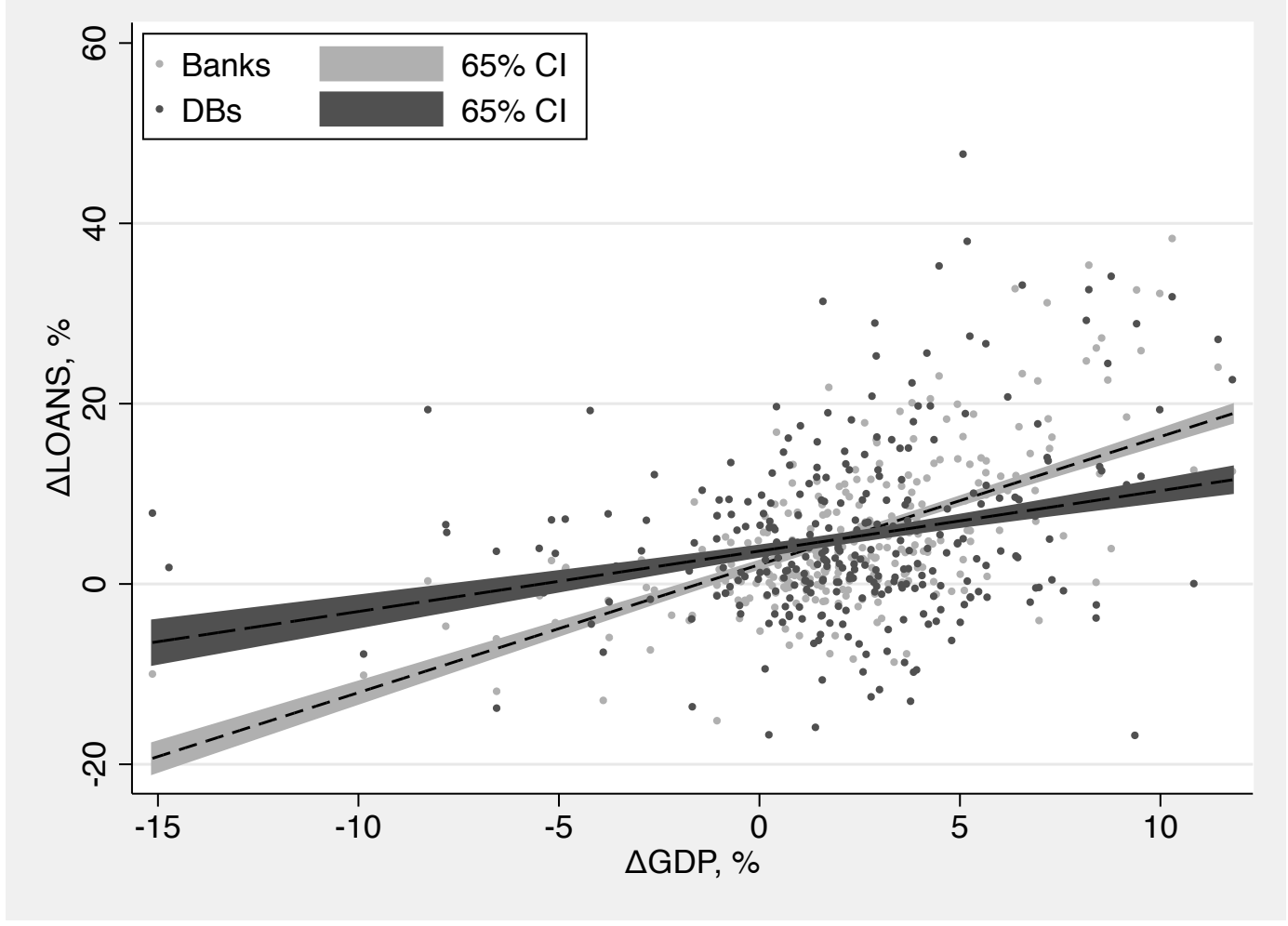

In the next section, we focus on econometrics with the aim of better disentangling the lending behavior of development banks from that of other financial institutions in the period before elections and to test the hypotheses formulated in Section 2.2.

\section{The model}

In order to meet the aim of this study, and therefore to assess whether the lending behavior of development banks is influenced by political considerations and opportunistic pre-electoral behavior, we investigate the different reactions of development banks to periods of political change, by interacting the election variable with a dummy that takes the value of one for development banks. As pointed out in Section 3.4, and in line with Micco et al. (2007), we also introduce GDP growth by country and year in order to control for the influence of the business cycle on loans growth and to take into account the possible correlation between electoral cycles and 
business cycles.

Our regression model is the following:

$$
Y_{i, c, t}=\sum_{k} \beta_{k} \cdot Z_{c, t}^{(k)} \cdot D B_{i}+\sum_{l} \delta_{l} \cdot X_{i, t-1}^{(l)}+\theta_{c, t}+\eta_{i}+\varepsilon_{i, c, t}
$$

where $Y_{i, c, t}\left(\equiv \Delta L O A N S_{i, c, t}\right)$ is loans growth, $D B_{i}$ is a dummy variable that takes value one if $i$ is a development bank, $Z_{c, t}^{(k)}$ is a set of time-variant country-specific variables, and $X_{i, t-1}^{(l)}$ is a set of time-variant bank-specific characteristics as of year $t-1$. The model also incorporates bank fixed effects $\eta_{i}$ and a set of country-year dummies $\theta_{c, t}$.

Following Dinc (2005) and Micco et al. (2007), we define loans growth $\left(Y_{i, c, t} \equiv \Delta L O A N S_{i, c, t}\right)$ as the change in loans in year $t$ divided by total assets in year $t$ 1. The set of time-variant country-specific variables include the GDP growth rate of country $c$ in year $t\left(Z_{c, t}^{(1)} \equiv \Delta G D P_{c, t}\right)$ and the election variable that measures to what extent year $t$ in country $c$ overlaps with an election season $\left(Z_{c, t}^{(2)} \equiv E L E C T_{c, t}\right)$.

The coefficient $\beta_{1}$ on the interaction term $\Delta G D P_{c, t} \cdot D B_{i}$ measures the differential effect of GDP growth on the loans growth of development banks with respect to other banks in their same countries. Positive (negative) values of $\beta_{1}$ would signal a more (less) pro-cyclical lending behavior of development banks with respect to the rest of the banking system. The coefficient $\beta_{2}$ on the interaction term $E L E C T_{c, t} \cdot D B_{i}$, which measures the differential effect induced by elections, is the coefficient of main interest for testing the hypotheses of Section 2.2. Indeed, a statistically significant coefficient would suggest that the electoral cycle affects the lending activity of the development banks to a different extent than it does for the other banks, consequently supporting a political view of development banks. In particular, we expect that $\beta_{2}$ is not significant in the whole sample (Hypothesis 1), while being positive and statistically significant in 
the subsample of "flawed democracies" (Hypothesis 2).

Taking into account our descriptive statistics of Section 3, we also include bankspecific control variables targeted at capturing size (the logarithm of lagged total assets, $X_{i, t-1}^{(1)} \equiv L T A_{i, t-1}$ ) and capitalization (the lagged equity-to-assets ratio, $X_{i, t-1}^{(2)} \equiv$ $\left.C A P_{i, t-1}\right)$ of bank $i$ at time $t-1$. We also include non-interest income as a share of total assets $\left(X_{i, t-1}^{(3)} \equiv N O N I N T_{i, t-1}\right)$, in order to control for the type of banking activity and the business model (Micco et al., 2007).

Bank fixed effects $\eta_{i}$ allow us to control for all the time-invariant differences between banks in the sample, including time-independent differences between development banks and the rest of the banking system, and institutional differences across their home countries. At the same time, the set of dummies for country-year specific effects $\theta_{c, t}$ controls for the omission of time-varying country-level variables, such as the inflation rate, the interest rates or yearly changes in exchange rates. Consequently, the inclusion of country-year fixed effects permits the comparison of differences in loans growth between development banks and non-development banks after controlling for all the unobserved country characteristics that are allowed to vary over time.

The coefficients of the static panel data model can be estimated using standard fixed effects (FE) or random effects (RE) estimators. The RE is more efficient than the FE estimator, but it relies on the additional assumption of no correlation between $\eta_{i}$ and $\varepsilon_{i, c, t}$. Since the Hausman test reveals a significant divergence between the FE and RE estimators, ${ }^{13}$ we reject the null hypothesis that individual effects are random and,

\footnotetext{
${ }^{13}$ The relevant value of the $\chi^{2}$-test is $\chi^{2}(353)=2312.52$, with a $p$-value $=0.0000$. The number of degrees of freedom $(d f=353)$ is shown in parentheses after the $\chi^{2}$.
} 
consequently, we adopt the FE approach. ${ }^{14}$

Finally, we recur to robust standard errors that account for possible heteroskedasticity or within-panel serial correlation in the idiosyncratic error term $\varepsilon_{i c t}$.

\section{Empirical results}

\subsection{Baseline estimations}

Table 2 shows the coefficients estimated for the whole sample in order to test Hypothesis 1. The first regression (column 1) focuses on the responses of the lending behavior to changes in the bank-specific characteristics, without distinguishing between development banks and other banks. ${ }^{15}$ The second regression (column 2) introduces a differential lending behavior of development banks over the business cycle by introducing the interaction term $\Delta G D P_{c, t} \cdot D B_{i}$. We find that the annual increase in loans relative to bank size is less sensitive to economic fluctuations for development banks than for the rest of the banking system, as indicated by the significant and negative coefficient on the interaction term. This lower sensitivity can be attributed to a more counter-cyclical stance of development banks with respect to other financial institutions, which is confirmed both in full and flawed democracies. Finally, the third regression (column 3) specifically tests the influence of the electoral cycle on the differential lending behavior of development banks, by introducing the interaction term $E L E C T_{c, t} \cdot D B_{i}$ and still controlling for the effects of economic fluctuations.

\footnotetext{
${ }^{14}$ Results obtained with RE did not lead to different conclusions (available upon request).

${ }^{15}$ As expected, the negative coefficients on LTA signal that higher bank size is accompanied by lower levels of loans growth ( $\triangle$ LOANS).
} 
For the overall sample, the coefficient on the interaction term is not significantly different from zero. This estimate shows that the lending activity of European development banks does not change during electoral years compared to that of other banks, thus providing no support for a political view of development banks.

Following the considerations of Section 3.1, we also rerun the regressions for different size classes: the smaller DBs' size class (columns 4-6), and the larger DBs' size class (columns 7-9). Interestingly, the coefficient on $\Delta G D P_{c, t} \cdot D B_{i}$ is more negative in the last subsample, thus suggesting that the counter-cyclical behavior of development banks is more relevant among larger banks. By contrast, the interaction term on $\operatorname{ELECT}_{c, t} \cdot D B_{i}$ is not significant in all of the estimations, failing to reject hypothesis 1 independently from the bank size.

Table 2 - Elections and lending activity Dependent variable: Change in Loans ( $\triangle$ LOANS)

\begin{tabular}{|c|c|c|c|c|c|c|c|c|c|}
\hline & \multicolumn{3}{|c|}{ Whole Sample } & \multicolumn{3}{|c|}{ Smaller DBs' size class } & \multicolumn{3}{|c|}{ Larger DBs' size class } \\
\hline & (1) & (2) & (3) & (4) & (5) & (6) & (7) & (8) & (9) \\
\hline LTA & $\begin{array}{c}-3.64^{* * * *} \\
{[0.40]}\end{array}$ & $\begin{array}{c}-3.65^{* * *} \\
{[0.40]}\end{array}$ & $\begin{array}{c}-3.65^{* * *} \\
{[0.40]}\end{array}$ & $\begin{array}{c}-4.78^{* * *} \\
{[0.42]}\end{array}$ & $\begin{array}{c}-4.79^{* * * *} \\
{[0.42]}\end{array}$ & $\begin{array}{c}-4.79^{* * *} \\
{[0.42]}\end{array}$ & $\begin{array}{c}-4.40^{* * *} \\
{[0.87]}\end{array}$ & $\begin{array}{c}-4.43^{* * *} \\
{[0.86]}\end{array}$ & $\begin{array}{c}-4.43^{* * * *} \\
{[0.86]}\end{array}$ \\
\hline NONINT & $\begin{array}{c}-0.00 \\
{[0.01]}\end{array}$ & $\begin{array}{c}-0.00 \\
{[0.01]}\end{array}$ & $\begin{array}{c}-0.00 \\
{[0.01]}\end{array}$ & $\begin{array}{c}0.01 \\
{[0.02]}\end{array}$ & $\begin{array}{c}0.01 \\
{[0.02]}\end{array}$ & $\begin{array}{c}0.01 \\
{[0.02]}\end{array}$ & $\begin{array}{c}0.08 \\
{[0.14]}\end{array}$ & $\begin{array}{c}0.09 \\
{[0.14]}\end{array}$ & $\begin{array}{c}0.09 \\
{[0.14]}\end{array}$ \\
\hline CAP & $\begin{array}{c}-0.01 \\
{[0.02]}\end{array}$ & $\begin{array}{c}-0.01 \\
{[0.02]}\end{array}$ & $\begin{array}{l}-0.01 \\
{[0.02]}\end{array}$ & $\begin{array}{c}-0.01 \\
{[0.03]}\end{array}$ & $\begin{array}{c}-0.01 \\
{[0.03]}\end{array}$ & $\begin{array}{c}-0.01 \\
{[0.03]}\end{array}$ & $\begin{array}{l}-0.11^{*} \\
{[0.06]}\end{array}$ & $\begin{array}{l}-0.11^{*} \\
{[0.06]}\end{array}$ & $\begin{array}{l}-0.11^{*} \\
{[0.06]}\end{array}$ \\
\hline & & $\begin{array}{c}-0.37^{* * *} \\
{[0.11]}\end{array}$ & $\begin{array}{c}-0.37^{* * *} \\
{[0.11]}\end{array}$ & & $\begin{array}{c}-0.38^{* * *} \\
{[0.13]}\end{array}$ & $\begin{array}{c}-0.38^{* * *} \\
{[0.13]}\end{array}$ & & $\begin{array}{c}-0.60^{* * *} \\
{[0.18]}\end{array}$ & $\begin{array}{c}-0.60^{* * *} \\
{[0.19]}\end{array}$ \\
\hline ELECT * DB & & & $\begin{array}{c}0.11 \\
{[0.84]}\end{array}$ & & & $\begin{array}{c}0.14 \\
{[1.14]}\end{array}$ & & & $\begin{array}{c}-0.09 \\
{[1.32]}\end{array}$ \\
\hline Bank f.e. & YES & YES & YES & YES & YES & YES & YES & YES & YES \\
\hline Country-year f.e. & YES & YES & YES & YES & YES & YES & YES & YES & YES \\
\hline Observations & 40,201 & 40,201 & 40,201 & 29,928 & 29,928 & 29,928 & 4,650 & 4,650 & 4,650 \\
\hline N. of countries & 27 & 27 & 27 & 27 & 27 & 27 & 24 & 24 & 24 \\
\hline $\mathrm{r} 2$ & 0.27 & 0.27 & 0.27 & 0.30 & 0.30 & 0.30 & 0.45 & 0.46 & 0.46 \\
\hline
\end{tabular}

The regression is run within separate size classes: (i) the whole sample (columns 1-3); (ii) the smaller DB's size class (columns 4-6), which includes banks in the percentiles 22-90 by total assets; (iii) the larger DBs' size class (columns 7-9), which includes banks above the 90th percentile (see Section 3.1 for details). The dependent variable $\Delta$ LOANS measures the change in total loans in year $t$ as a share of total assets in year $t$ - 1 . LTA is the logarithm of lagged total assets in EUR thousands. NONINT is the lagged share of non-interest income over average total assets (i.e. the average of total assets at the beginning of the year and at the year's end). CAP is the lagged share of total equity over total assets. $\triangle$ GDP is the GDP growth rate by country and year. ELECT is the share of the year $t$ that falls within the twelve months prior to a national election in country $c$. DB is a dummy variable that takes the value of one for development banks. The reference period is 2002-2015. Robust standard errors in brackets. Significance levels: ${ }^{*} p<0.1,{ }^{* *} p<0.05,{ }^{* * *} p<0.01$ 
However, it could be still possible that development banks are more likely to increase lending in election years if they are located in countries with flawed democracies and lower constraints on the executive power. Therefore, in Table 3 we test Hypothesis 2 by running the same regressions for the subsamples of "full democracies" $(\mathrm{DEMOC}=10)$ and "flawed democracies" $(\mathrm{DEMOC}<10)$ respectively. When splitting the sample according to the level of constitutional democratic development of each country, the coefficient of the interaction term $E L E C T_{c, t} \cdot D B_{i}$ is still non-significant for the "full democracies" subsample (columns 1-3), confirming no support for a political view of development banks in countries with the highest level of institutional quality.

By contrast, the coefficient of the interaction term $E L E C T_{c, t} \cdot D B_{i}$ is significant at the five percent level and strongly positive for the subsample of "flawed democracies" when the analysis is limited to larger development banks and other banks of comparable size (column 9). This empirical evidence supports the Hypothesis 2 that before elections development banks located in countries with flawed democracies increase their lending activity relatively more than other banks in their same countries, thus revealing that their lending decisions are actually more exposed to the pre-electoral, opportunistic behavior of the incumbent policymaker. The fact that this evidence is only confirmed in larger banks makes perfect sense. Indeed, it is reasonable to expect that only larger development banks have the necessary firepower to affect specific segments of the economy in the short-term, thus increasing the chances of the incumbent to be reelected. Then, it is just on larger development banks that policymakers eventually focus their opportunistic pressures. However, the subsample of larger development banks located in flawed democracies only includes few institutions, thus suggesting that 
evidence of opportunistic pre-electoral behavior can only be reported for a very limited

set of development banks.

Table 3 - Elections and lending activity: subsample regressions by DEMOC levels

Dependent variable: Change in Loans ( $\triangle$ LOANS)

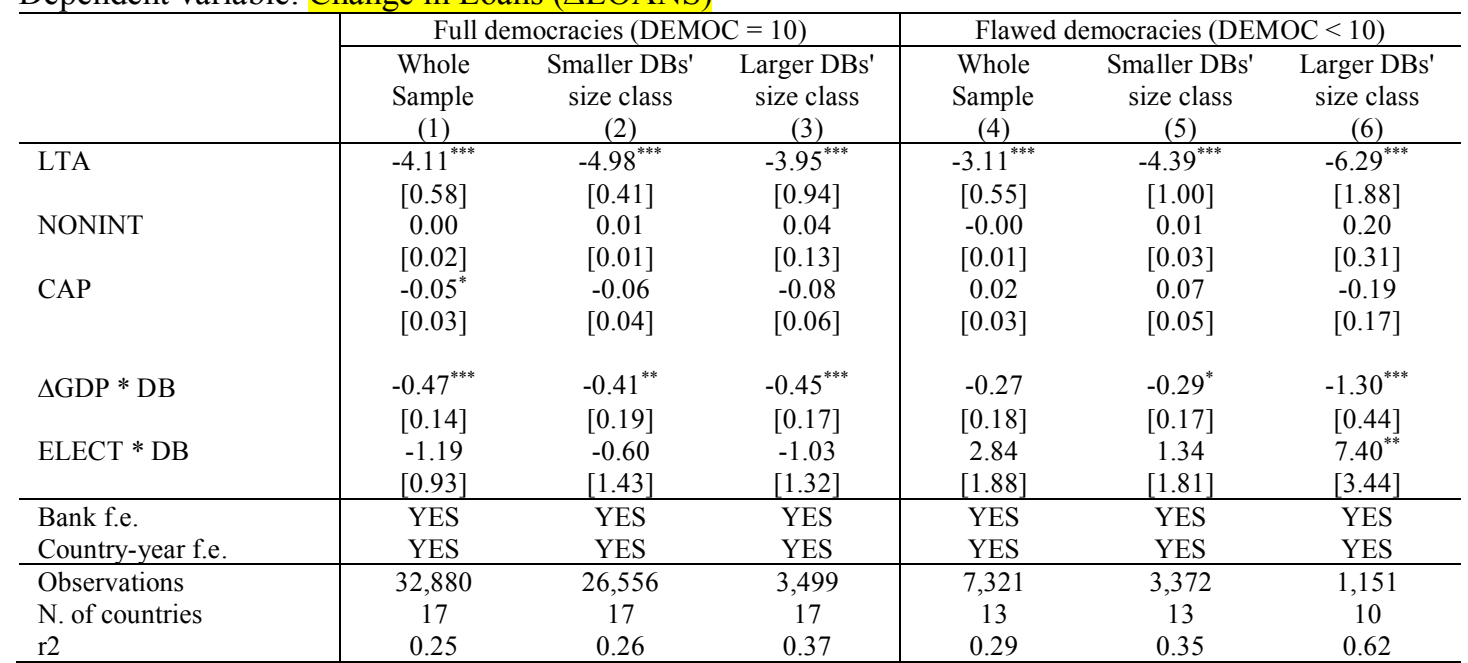

The sample is split based the level of constitutional democratic development (DEMOC), measured by the Polity IV Project on a zero-to-ten scale, with ten indicating "full democracy" and lower levels indicating "flawed democracies". Countries are allowed to move from one group to another according to the annual value of DEMOC. The regression is run within separate size classes: (i) the whole sample (columns 1 and 4); (ii) the smaller DB's size class (columns 2 and 5), which includes banks in the percentiles 22-90 by total assets; (iii) the larger DBs' size class (columns 3 and 6), which includes banks above the 90th percentile (see Section 3.1 for details). The dependent variable $\triangle$ LOANS measures the change in total loans in year $t$ as a share of total assets in year $t-1$. LTA is the logarithm of lagged total assets in EUR thousands. NONINT is the lagged share of non-interest income over average total assets (i.e. the average of total assets at the beginning of the year and at the year's end). CAP is the lagged share of total equity over total assets. $\triangle$ GDP is the GDP growth rate by country and year. ELECT is the share of the year $t$ that falls within the twelve months prior to a national election in country $c$. DB is a dummy variable that takes the value of one for development banks. The reference period is 2002-2015. Robust standard errors in brackets.

Significance levels: ${ }^{*} p<0.1,{ }^{* *} p<0.05,{ }^{* * *} p<0.01$

In Table 3, all the coefficients are allowed to vary across the two subsamples, since we run separate regressions for "full democracies" and "flawed democracies" respectively. Although our main interest is on the significance of the interaction term $E L E C T_{c, t} \cdot D B_{i}$ within each group of countries, we are aware that separate regressions do not determine whether the coefficient on the interaction term is statistically different across the groups. By running a unique regression for the whole sample and adding a triple interaction term, we actually verified that the coefficient on $E L E C T_{c, t} \cdot D B_{i}$ is 
significantly higher in flawed democracies than in full democracies when considering the size class of larger development banks (see Table A.2 in the Appendix).

Besides, we also verified that similar conclusions can be reached if we do not run separate regressions by size classes and we adopt a weighting strategy. According to Micco et al. (2007) and Yeyati and Micco (2003), adopting a weighting scheme that assigns a higher weight to larger banks may produce more precise estimates if higher bank size is associated with lower measurement errors. Furthermore, given the larger weight assigned to larger banks, this weighting scheme may better reflect the comparison of the lending behavior of development banks with that of the banking industry at an aggregate level, implicitly presuming that the aggregate behavior of credit demand and supply is more influenced by changes observed in largest banks. Accordingly, we also rerun our baseline estimations weighting each bank-year observation by the bank's share of lagged total assets within the whole dataset in the same year, so that the weight for bank $i$ at time $t$ is given by $w_{i, t}=\frac{T A_{i, t-1}}{\sum_{j=1}^{N} T A_{j, t-1}} \cdot{ }^{16}$ Estimations obtained after the adoption of the weighting scheme do not contradict our main results (see Table A.3 of the Appendix), confirming that the lending activity of European development banks does not change during electoral years compared to that of other banks, with the exception of "flawed democracies" where the lending behavior of development banks is more exposed to the pre-electoral, opportunistic behavior of the incumbent policymaker (the coefficient on $E L E C T_{c, t} \cdot D B_{i}$ is strongly positive and

\footnotetext{
${ }^{16}$ Since the weighting scheme assigns higher weights to years with a lower number of observations (the denominator $\sum_{j=1}^{N} T A_{j, t-1}$ tends to decrease with the number of available observations in year t-1), it may also have the advantage of correcting the estimations for the different number of observations in different years, since data availability in the dataset tend to increase over time.
} 
significant at the 1 percent level in flawed democracies). Besides, the counter-cyclical behavior of development banks (i.e. the negative coefficient on $\Delta G D P_{c, t} \cdot D B_{i}$ ) is confirmed in both full and flawed democracies.

Overall, the results of this section may be regarded as in line with those obtained from Dinc (2005) and Micco et al. (2007) who did not find support for the political view of state-owned banks in industrial countries, while pointing out that the lending stance of state-owned banks in emerging countries becomes significantly more accommodating in election years. However, our investigation is specifically focused on contemporary development banks, which differ from other state-owned banks because of their distinctive mandates and targets (see Section 2.1).

\subsection{Additional analyses}

The behavior of development banks in flawed democracies over the electoral cycle deserves further investigation. Indeed, an increase in development banks' lending during election years may simply represent the response to higher demand for development banks' loans in pre-electoral months, rather than the effect of opportunistic behavior. The pattern of interest margins may provide some further explanation. Indeed, following the reasoning of Micco et al. (2007), the absence of a significant increase in interest income of development banks during election years would lead to excluding the possibility that the corresponding increase in development banks' lending simply represents the response to higher demand. Consequently, our next analysis focuses on the interest rate charged by banks (proxied by the ratio of interest income over earning assets, INTINC) as a dependent variable. Table 4 shows that no differential effects characterize the behavior of interest income over earning assets in development banks with respect to the rest of the banking system across the cycles (the coefficients on $E L E C T_{c, t} \cdot D B_{i}$ are never statistically significant). This 
evidence is confirmed in both full democracies and flawed democracies, independently

from size class. Then, the positive change in loans extended by large development banks during election years in flawed democracies is more likely to reflect political influence on their activity and the will to finance businesses in exchange for higher electoral support.

Table 4 - Elections and interest margin

Dependent variable: INTINC

\begin{tabular}{|c|c|c|c|c|c|c|}
\hline & \multicolumn{2}{|c|}{ All countries } & \multicolumn{2}{|c|}{$\begin{array}{c}\text { Full democracies } \\
(\mathrm{DEMOC}=10)\end{array}$} & \multicolumn{2}{|c|}{$\begin{array}{c}\text { Flawed democracies } \\
(\text { DEMOC }<10)\end{array}$} \\
\hline & $\begin{array}{c}\text { Smaller DBs' } \\
\text { size class } \\
\text { (1) }\end{array}$ & $\begin{array}{c}\text { Larger DBs' } \\
\text { size class } \\
\text { (2) }\end{array}$ & $\begin{array}{c}\text { Smaller DBs' } \\
\text { size class } \\
\text { (3) }\end{array}$ & $\begin{array}{c}\text { Larger DBs' } \\
\text { size class } \\
\text { (4) }\end{array}$ & $\begin{array}{c}\text { Smaller DBs' } \\
\text { size class } \\
(5)\end{array}$ & $\begin{array}{c}\text { Larger DBs' } \\
\text { size class } \\
(6)\end{array}$ \\
\hline LTA & $\begin{array}{c}0.10 \\
{[0.11]}\end{array}$ & $\begin{array}{l}-0.03 \\
{[0.19]}\end{array}$ & $\begin{array}{c}0.03 \\
{[0.10]}\end{array}$ & $\begin{array}{l}-0.11 \\
{[0.20]}\end{array}$ & $\begin{array}{c}0.27 \\
{[0.28]}\end{array}$ & $\begin{array}{c}0.14 \\
{[0.51]}\end{array}$ \\
\hline NONINT & $\begin{array}{c}0.01 \\
{[0.00]}\end{array}$ & $\begin{array}{c}0.11 \\
{[0.08]}\end{array}$ & $\begin{array}{l}-0.00 \\
{[0.01]}\end{array}$ & $\begin{array}{c}0.14 \\
{[0.09]}\end{array}$ & $\begin{array}{l}0.01^{* *} \\
{[0.01]}\end{array}$ & $\begin{array}{l}-0.05 \\
{[0.05]}\end{array}$ \\
\hline CAP & $\begin{array}{l}0.02^{* *} \\
{[0.01]}\end{array}$ & $\begin{array}{c}0.01 \\
{[0.02]}\end{array}$ & $\begin{array}{c}0.02 \\
{[0.02]}\end{array}$ & $\begin{array}{l}-0.01 \\
{[0.02]}\end{array}$ & $\begin{array}{l}0.03^{* *} \\
{[0.01]}\end{array}$ & $\begin{array}{l}0.08^{* *} \\
{[0.04]}\end{array}$ \\
\hline$\Delta \mathrm{GDP} * \mathrm{DB}$ & $\begin{array}{c}0.10^{*} \\
{[0.05]}\end{array}$ & $\begin{array}{c}0.01 \\
{[0.05]}\end{array}$ & $\begin{array}{l}-0.03 \\
{[0.09]}\end{array}$ & $\begin{array}{c}0.02 \\
{[0.02]}\end{array}$ & $\begin{array}{l}0.19^{* * *} \\
{[0.07]}\end{array}$ & $\begin{array}{l}-0.10 \\
{[0.15]}\end{array}$ \\
\hline ELECT* DB & $\begin{array}{l}-0.74 \\
{[0.58]}\end{array}$ & $\begin{array}{c}0.27 \\
{[0.26]}\end{array}$ & $\begin{array}{l}-1.10 \\
{[0.75]}\end{array}$ & $\begin{array}{c}0.09 \\
{[0.16]}\end{array}$ & $\begin{array}{l}-0.36 \\
{[0.95]}\end{array}$ & $\begin{array}{c}1.97 \\
{[1.45]}\end{array}$ \\
\hline Bank f.e. & YES & YES & YES & YES & YES & YES \\
\hline Country-year f.e. & YES & YES & YES & YES & YES & YES \\
\hline Observations & 29,799 & 4,622 & 26,467 & 3,483 & 3,332 & 1,139 \\
\hline N. of countries & 27 & 24 & 17 & 17 & 13 & 10 \\
\hline $\mathrm{r} 2$ & 0.49 & 0.42 & 0.65 & 0.51 & 0.28 & 0.38 \\
\hline
\end{tabular}

In columns 3-6, the sample is split based the level of constitutional democratic development (DEMOC), measured by the Polity IV Project on a zero-to-ten scale, with ten indicating "full democracy" and lower levels indicating "flawed democracies". Countries are allowed to move from one group to another according to the annual value of DEMOC. The regression is run within separate size classes: (i) the smaller DB's size class (columns 1, 3, and 5), which includes banks in the percentiles 22-90 by total assets; (ii) the larger DBs' size class (columns 2, 4, and 6), which includes banks above the 90th percentile (see Section 3.1 for details). The dependent variable INTINC measures interest income as a share of average interest earning assets (i.e. the average of earning assets at the beginning of the year and at the year's end). LTA is the logarithm of lagged total assets in EUR thousands. NONINT is the lagged share of non-interest income over average total assets (i.e. the average of total assets at the beginning of the year and at the year's end). CAP is the lagged share of total equity over total assets. $\Delta$ GDP is the GDP growth rate by country and year. ELECT is the share of the year $t$ that falls within the twelve months prior to a national election in country $c$. DB is a dummy variable that takes the value of one for development banks. The reference period is 2002-2015. Robust standard errors in brackets.

Significance levels: ${ }^{*} p<0.1,{ }^{* *} p<0.05,{ }^{* * *} p<0.01$

A similar regression (available on request) introducing operating expenditures over total assets (OPEX) as dependent variable reveals that cost efficiency depends on the bank size (negative coefficient on LTA) and the type of business model (positive coefficient on NONINT), but no differential effects are found for development banks 
over the electoral cycles, apart from smaller development banks in flawed democracies (the coefficient on $E L E C T_{c, t} \cdot D B_{i}$ is positive and significant at the 5 percent level in flawed democracies when considering the smaller development banks' size class). This evidence suggests that where the political view applies to development banks, it primarily applies through the lending channel, although we cannot completely exclude the existence of political pressures on smaller development banks in flawed democracies intended to increase the number of employees in exchange for political support.

\section{Robustness checks}

In this section, we test the robustness of our baseline findings on the behavior of loans growth ( $\triangle L O A N S$ ) over the cycles with respect to different measures for our electoral and institutional variables (Table 5 and 6) or different specifications of the regression model (Tables 7 and 8).

\subsection{Alternative measures of electoral and institutional variables}

Firstly, we repeat our estimations introducing different definitions of the election variable $E L E C T_{c, t}$ with respect to the continuous measure presented in Section 3.3. Following the procedure adopted by Dinc (2005), we alternatively define $E L E C T_{c, t}$ as a dummy variable that takes the value of one when elections take place. Year $t$ is defined as an electoral year for country $c$ if the elections are held between April of year $t$ and March of year $t+1$. Again, the underlying assumption is that electoral incentives anticipate the elections themselves by some months.

Table 5 shows that the main findings of our baseline estimations are entirely confirmed when considering this alternative election variable. The coefficient on $E_{E E C T_{c, t}} \cdot D B_{i}$ is still positive and significant (at the 5 percent level) only in flawed 
democracies when considering the size class of larger development banks. By contrast, in full democracies the negative coefficient becomes significant at the 1 percent level, providing no evidence of opportunistic pre-electoral behavior of development banks.

Table 5 - Elections and lending activity: timing of elections (April-March dummy)

Dependent variable: Change in Loans ( $\triangle$ LOANS)

\begin{tabular}{|c|c|c|c|c|c|c|}
\hline & \multicolumn{2}{|c|}{ All countries } & \multicolumn{2}{|c|}{$\begin{array}{c}\text { Full democracies } \\
(\mathrm{DEMOC}=10)\end{array}$} & \multicolumn{2}{|c|}{$\begin{array}{l}\text { Flawed democracies } \\
(\text { DEMOC }<10)\end{array}$} \\
\hline & $\begin{array}{c}\text { Smaller DBs' } \\
\text { size class } \\
(1) \\
\end{array}$ & $\begin{array}{c}\text { Larger DBs' } \\
\text { size class } \\
(2) \\
\end{array}$ & $\begin{array}{c}\text { Smaller DBs' } \\
\text { size class } \\
(3) \\
\end{array}$ & $\begin{array}{c}\text { Larger DBs' } \\
\text { size class } \\
(4) \\
\end{array}$ & $\begin{array}{c}\text { Smaller DBs' } \\
\text { size class } \\
(5) \\
\end{array}$ & $\begin{array}{c}\text { Larger DBs' } \\
\text { size class } \\
(6) \\
\end{array}$ \\
\hline $\begin{array}{l}\text { LTA } \\
\end{array}$ & $\begin{array}{c}-4.79^{* * *} \\
{[0.42]}\end{array}$ & $\begin{array}{c}-4.43^{* * *} \\
{[0.86]}\end{array}$ & $\begin{array}{c}-4.97^{* * *} \\
{[0.41]}\end{array}$ & $\begin{array}{c}-3.95^{* * *} \\
{[0.94]}\end{array}$ & $\begin{array}{c}-4.39^{* * *} \\
{[1.00]}\end{array}$ & $\begin{array}{c}-6.35^{* * *} \\
{[1.88]}\end{array}$ \\
\hline NONINT & $\begin{array}{c}0.01 \\
{[0.02]}\end{array}$ & $\begin{array}{c}0.09 \\
{[0.13]}\end{array}$ & $\begin{array}{c}0.01 \\
{[0.01]}\end{array}$ & $\begin{array}{c}0.05 \\
{[0.12]}\end{array}$ & {$[0.01$} & $\begin{array}{c}0.21 \\
{[0.32]}\end{array}$ \\
\hline CAP & $\begin{array}{l}-0.01 \\
{[0.03]}\end{array}$ & $\begin{array}{l}-0.11^{*} \\
{[0.06]}\end{array}$ & $\begin{array}{l}-0.06 \\
{[0.04]}\end{array}$ & $\begin{array}{l}-0.08 \\
{[0.06]}\end{array}$ & $\begin{array}{c}0.07 \\
{[0.05]}\end{array}$ & $\begin{array}{l}-0.19 \\
{[0.17]}\end{array}$ \\
\hline$\Delta \mathrm{GDP} * \mathrm{DB}$ & $\begin{array}{c}-0.37^{* * *} \\
{[0.13]}\end{array}$ & $\begin{array}{c}-0.60^{* * *} \\
{[0.18]}\end{array}$ & $\begin{array}{c}-0.39^{* *} \\
{[0.20]}\end{array}$ & $\begin{array}{c}-0.46^{* * *} \\
{[0.14]}\end{array}$ & $\begin{array}{l}-0.29^{*} \\
{[0.17]}\end{array}$ & $\begin{array}{c}-1.23^{* * *} \\
{[0.43]}\end{array}$ \\
\hline ELECT* DB & $\begin{array}{c}0.42 \\
{[0.86]}\end{array}$ & $\begin{array}{c}-0.11 \\
{[0.94]}\end{array}$ & $\begin{array}{c}0.51 \\
{[1.11]}\end{array}$ & $\begin{array}{l}-1.32^{*} \\
{[0.75]}\end{array}$ & $\begin{array}{l}-0.02 \\
{[1.31]}\end{array}$ & $\begin{array}{l}6.50^{* *} \\
{[3.07]}\end{array}$ \\
\hline $\begin{array}{l}\text { Bank f.e. } \\
\text { Country-year f.e. }\end{array}$ & $\begin{array}{l}\text { YES } \\
\text { YES }\end{array}$ & $\begin{array}{l}\text { YES } \\
\text { YES }\end{array}$ & $\begin{array}{l}\text { YES } \\
\text { YES }\end{array}$ & $\begin{array}{l}\text { YES } \\
\text { YES }\end{array}$ & $\begin{array}{l}\text { YES } \\
\text { YES }\end{array}$ & $\begin{array}{l}\text { YES } \\
\text { YES }\end{array}$ \\
\hline $\begin{array}{l}\text { Observations } \\
\text { N. of countries } \\
\text { r2 }\end{array}$ & $\begin{array}{c}29,928 \\
27 \\
0.30\end{array}$ & $\begin{array}{c}4,650 \\
24 \\
0.46\end{array}$ & $\begin{array}{c}26,556 \\
17 \\
0.26\end{array}$ & $\begin{array}{c}3,499 \\
17 \\
0.37\end{array}$ & $\begin{array}{c}3,372 \\
13 \\
0.35\end{array}$ & $\begin{array}{c}1,151 \\
10 \\
0.62\end{array}$ \\
\hline
\end{tabular}

In columns 3-6, the sample is split based the level of constitutional democratic development (DEMOC), measured by the Polity IV Project on a zero-to-ten scale, with ten indicating "full democracy" and lower levels indicating "flawed democracies". Countries are allowed to move from one group to another according to the annual value of DEMOC. The regression is run within separate size classes: (i) the smaller DB's size class (columns 1,3, and 5), which includes banks in the percentiles 22-90 by total assets; (ii) the larger DBs' size class (columns 2, 4, and 6), which includes banks above the 90th percentile (see Section 3.1 for details). The dependent variable $\triangle$ LOANS measures the change in total loans in year $t$ as a share of total assets in year $t-1$. LTA is the logarithm of lagged total assets in EUR thousands. NONINT is the lagged share of non-interest income over average total assets (i.e. the average of total assets at the beginning of the year and at the year's end). CAP is the lagged share of total equity over total assets. $\triangle$ GDP is the GDP growth rate by country and year. ELECT is a dummy variable that takes the value of one if elections in country $c$ occurred between April of year $t$ and March of year $t+1$. DB is a dummy variable that takes the value of one for development banks. The reference period is 20022015. Robust standard errors in brackets.

Significance levels: ${ }^{*} p<0.1,{ }^{* *} p<0.05,{ }^{* * *} p<0.01$

One relevant identification assumption is that the lending activity of both development banks and non-development banks should follow parallel trends in nonelection years, i.e. it should behave similarly in the two groups, once controlling for other relevant derminants. In order to check if the assumption of parallel trends is fulfilled, we performed a counterfactual analysis in which the post-election year is chosen as the event that identifies a NON-ELECT dummy, to be tested in alternative to 
the ELECT dummy of Table 5. This counterfactual analysis found no differential effects in the lending patterns of large development banks in flawed democracies in the post-election year (results available upon request). This evidence increases our confidence that the differential effects obtained in the previous analyses are just due to the election event.

In addition, the positive coefficient on the interaction term for larger development banks in flawed democracies is also confirmed when simply considering [January, year $t$; December, year $t$ ] as the reference time window to identify the electoral year, instead of the convention [April, year $t$; March, year $t+1$ ]. Consequently, we can conclude that our main findings are not affected by the choice of the convention adopted to identify our electoral dummy.

Similarly, we are interested to know how our main results change when splitting the sample according to other country-level institutional variables rather than our indicator of constitutional democratic development (DEMOC). First, we repeated the analysis considering the distinct subcomponents of the DEMOC indicator, according to the measures provided by the Polity IV Project. Interestingly, the specific subcomponent that affects more the difference of estimates between "full democracies" and "flawed democracies" is the XCONST indicator. XCONST measures Executive Constraints on a zero-to-seven scale, where the higher values indicate stronger institutionalized constraints on the decision-making powers of chief executives. When we separately analyze countries with "full constraints on chief executive" (XCONST =7) and countries with "flawed constraints on chief executive" (XCONST $<7$ ), we find that the coefficient on $E L E C T_{c, t} \cdot D B_{i}$ is not significant in countries with full constraints on chief executive, while it is positive and significant (at the 10 percent level) in countries with flawed constraints when considering larger banks. This evidence suggests that pre- 
electoral, opportunistic pressures of the incumbent policymakers on development banks are less likely to occur in consolidated democracies where accountability groups (such as the legislature) have a relevant and effective authority in front of the executive power.

We also adopt alternative country indexes, such as the Worldwide Governance Indicators (WGI), ${ }^{17}$ in order to test whether alternative measures of institutional quality have the same ability to isolate those countries where the political view of development banks is supported by empirical evidence. Table 6 shows the coefficients estimated on $\Delta G D P_{c, t} \cdot D B_{i}$ and $E L E C T_{c, t} \cdot D B_{i}$ (the other coefficients are not reported for the sake of brevity) when splitting the sample based on two different Governance Indicators: "voice and accountability" (VA) and "regulatory quality" $(R Q)$. We run separate estimations for countries with high and low levels of these indicators, where high levels correspond with the top tercile of countries and low levels include the remaining countries. Once again, the negative coefficient on $\Delta G D P_{c, t} \cdot D B_{i}$ confirms the countercyclical role played by development banks in almost all the subgroups. More importantly, the coefficient on $E L E C T_{c, t} \cdot D B_{i}$ is still positive and significant at the 10 percent level in countries with lower institutional quality (i.e. low levels of VA and RQ). ${ }^{18}$ Note also that two additional WGI indicators ("rule of law" and "control of

\footnotetext{
${ }^{17}$ See Kaufmann et al. (2010).

${ }^{18}$ By contrast, the coefficient on the same interaction term is negative and significantly different from zero (at the 5 percent level) when considering the larger size classes in countries with high levels of VA and RQ (columns 3). Since this result is apparently counterintuitive (the coefficients would the expected to be non-significant), we also run the same regression without including country-year fixed effects and adding the non-interacted variables ELECT and GDP, in order to measure the specific effects of political elections and GDP growth on the lending behavior of non-development banks. We find that the negative interaction term on ELECT * DB is due to a significant increase in the lending activity of large nondevelopment banks rather than to a decrease in the lending activity of large development banks. While several reasons may justify this empirical evidence for non-development banks (e.g. a different behavior
} 
corruption") lead to identical results, since they imply the same sample split based on

RQ. Overall, better legal and political institutions are confirmed to act as a defense against opportunistic political pressures and interferences on the lending activity of development banks.

Table 6 - Elections and lending activity: alternative country indexes

Dependent variable: Change in Loans ( $\triangle$ LOANS)

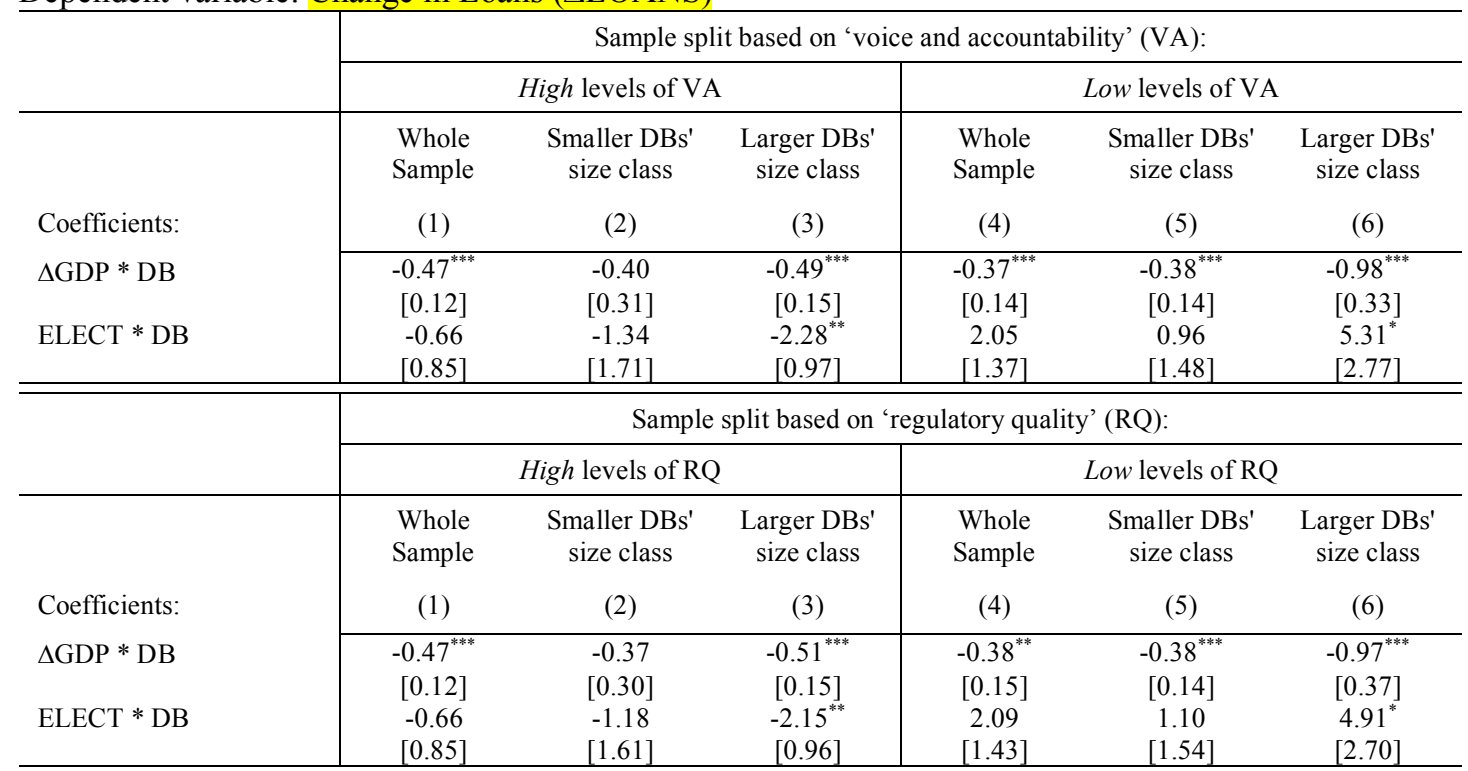

The sample is split based on alternative Worldwide Governance Indicators (WGI), and specifically: "voice and accountability" (VA) and "regulatory quality" (RQ). High levels include the top tercile of European countries ranked in terms of each indicator. Low levels include the remaining countries. The regression is run within separate size classes: (i) the whole sample (columns 1 and 4); (ii) the smaller DB's size class (columns 2 and 5), which includes banks in the percentiles 22-90 by total assets; (iii) the larger DBs' size class (columns 3 and 6), which includes banks above the 90th percentile (see Section 3.1 for details). The dependent variable $\Delta$ LOANS measures the change in total loans in year $t$ as a share of total assets in year $t-1 . \Delta \mathrm{GDP}$ is the GDP growth rate by country and year. ELECT is the share of the year $t$ that falls within the twelve months prior to a national election in country $c$. DB is a dummy variable that takes the value of one for development banks. The following explanatory variables are also included in the regressions, although the estimated coefficients are not reported for the sake of brevity: the logarithm of lagged total assets in EUR thousands (LTA); the lagged share of non-interest income over average total assets (NONINT); the lagged share of total equity over total assets (CAP). All the estimations include bank fixed effects and country-year fixed effects. The reference period is 2002-2015. Robust standard errors in brackets.

Significance levels: ${ }^{*} p<0.1,{ }^{* *} p<0.05,{ }^{* * *} p<0.01$

of credit demand around political elections, or a redistribution of credit supply from smaller banks to larger banks before elections), what is relevant for our analysis is that there is no evidence of development banks changing their lending behavior opportunistically before elections in countries with higher institutional quality. 
Interestingly, in Europe, the splitting based on constitutional democratic development and institutional quality is also largely reflected in the geographical division between Western and Eastern Europe, since historical reasons stand behind the different levels of democratic consolidation and the strength of rules and institutions that govern economic and social interactions. A sample split based on this geographical divide reveals that the positive coefficient on the interaction term $E L E C T_{c, t} \cdot D B_{i}$ is actually confirmed in the subsample of Eastern European countries independently from the size classes, but not in Western Europe (see Table A.5 in the Appendix). ${ }^{19}$ This evidence adds relevant information to our analysis, considering the particularly important role that development banks have played in the transformation of the Eastern European centralized economies into market economies after the Soviet collapse. Differences in the lending structure and the banking systems between the two groups of countries may contribute to explain the different lending behavior of development banks with respect to other banks, adding to the political aspects mentioned above.

In line with these last considerations, we also replicated our regressions controlling for European Union membership (results available upon request). Indeed, some Central and Eastern European countries entered the European Union during the time span considered. This event may affect the banking system and somehow interfere with our estimation of the lending behavior of development banks in pre-election periods. Results obtained after including an EU dummy, which is equal to 1 starting from the

\footnotetext{
${ }^{19}$ Specifically, the 27 countries of our sample are split in the following two macro-areas: (i) Western Europe, including older EU member states and EFTA countries (Austria, Belgium, Denmark, Finland France, Germany, Italy, Luxembourg, the Netherlands, Norway, Spain, Sweden, and the United Kingdom); (ii) Eastern Europe, including newer EU member states, CEFTA countries and other member countries of the Commonwealth of Independent States Free Trade Area (Bulgaria, Belarus, Croatia, the Czech Republic, Estonia, Hungary, Macedonia, Poland, Romania, Russia, Slovakia, Slovenia, Turkey and Ukraine).
} 
first year $t$ that a country $c$ enter the European Union, does not affect our main conclusions.

\subsection{Alternative specifications}

The model presented in Section 4 assumes that the data generating process is accurately described by static relationships. However, our baseline estimations may be severely biased by the exclusion of lagged dependent variables in the model specification. In this section, we introduce one or more lagged dependent variables, allowing for the modeling of a partial adjustment mechanism. Then, we can rewrite our model as:

$$
Y_{i, c, t}=\sum_{j} \alpha_{j} \cdot Y_{i, c, t-j}+\sum_{k}\left(\beta_{k} \cdot Z_{c, t}^{(k)} \cdot D B_{i}+\gamma_{k} \cdot Z_{c, t}^{(k)}\right)+\sum_{l} \delta_{l} \cdot X_{i, t-1}^{(l)}+\theta_{t}+\eta_{i}+\varepsilon_{i, c, t}
$$

where $Y_{i, c, t}, Z_{c, t}^{(k)}$, and $X_{i, t-1}^{(l)}$ are exactly the same variables defined in section 4 . Then, in the new specification of the model we just apply the following changes: (i) we introduce $j$ lags of the dependent variable among the regressors; (ii) we substitute the set of dummies for country-year effects $\theta_{c, t}$ with year dummies $\theta_{t}$; (iii) we include in the estimation model the non-interacted variables $Z_{c, t}^{(k)}$ (i.e. $E L E C T_{c, t}$ and $\Delta G D P_{c, t}$ ) since they are no more absorbed by country-year dummies.

The choice to remove the country-year dummies is justified by the need to reduce the 'too many instruments' problem that typically characterizes the dynamic panel estimators (Roodman, 2009). On the one hand, this choice prevents us from controlling for all the possible country-year effects. On the other hand, it permits us to measure the specific effects of political elections and GDP growth on the lending behavior of nondevelopment banks (and not only the differential effect on the lending behavior of development banks). Then, the impact of $Z_{c, t}^{(k)}$ on loans growth is given by $\beta_{k}$ for the 
non-development banks, while $\beta_{k}+\gamma_{k}$ measures the impact for development banks. The estimation of $\beta_{k}$ adds interesting information to our analysis although the coefficient on the interaction term $\gamma_{k}$ is still the relevant one in order to test our main hypotheses.

Once dynamic relationships (i.e. lagged dependent variables) are introduced, least squares methods on fixed effects or random effects models produce biased and inconsistent estimates (see Baltagi, 2001). Nickell (1981) shows that this bias is especially larger in a context of 'short-T, large-N' dataset. One common approach to deal with dynamic panel data models involves the generalized method-of-moments (GMM) (Hansen, 1982). In particular, we recur to system GMM estimators developed by Arellano and Bover (1995) and Blundell and Bond (1998). System GMM estimation: (a) transforms the regression equation to remove any omitted variable bias created by unobserved heterogeneity (bank-specific effects); (b) instruments the right-hand-side variables of the transformed equation using lagged values of the original regressors to eliminate potential parameter inconsistency arising from the dynamic panel bias; (c) combines the transformed equation in a system with the original regression in levels, in order to improve efficiency and consistency. The instruments for the regression in levels are the lagged differences.

The system GMM estimator offers relevant improvements upon the difference GMM estimator (Holtz-Eakin et al., 1988; Arellano and Bond, 1991), which excludes step (c), due to the higher quality of the internal instruments. ${ }^{20}$ However, it requires an additional assumption that changes in any instrumenting variables are uncorrelated with

\footnotetext{
${ }^{20}$ Indeed, the lagged levels are rather weak instruments for the regression equation in differences, especially when the explanatory variables are persistent over time. This weak instrument problem can induce biases in finite samples and poor precision even asymptotically.
} 
the bank-specific effects. Since postestimation tests seem to confirm that these additional restrictions are not to be rejected, we base our estimation approach on the system GMM estimator. $^{21}$

In our system GMM estimation, the transformed equation of step (b) is obtained by recurring to 'forward orthogonal deviations' (Arellano and Bover, 1995). ${ }^{22}$ Moreover, instruments are 'collapsed' in order to efficiently correct for instrument proliferation (Roodman, 2009). Finally, we use two-step GMM estimation and the Windmeijer correction, which adjusts the covariance matrix to minimize the downward bias of the two-step standard errors in finite samples (Windmeijer, 2005). Standard errors are heteroskedasticity and autocorrelation robust and clustered by the panel identifier, i.e., individual banks.

For comparison, Table 7 summarizes the results obtained with three alternative econometric procedures: Pooled OLS regressions (columns 1, 4, and 7), fixed effects OLS regressions (columns 2, 5, and 8), and system GMM (columns 3, 6, and 9). Once again, we split the sample based on the DEMOC variable at the country level, and all the regressions are performed in the different size classes considered. The coefficients

\footnotetext{
${ }^{21}$ Since the aim of this work is to test the existence of an opportunistic behavior of development banks in election periods (i.e. a positive and significant coefficient on the ELECT * DB interaction term), our preference for the system GMM also represents a conservative choice, since difference GMM produces higher standard errors and, consequently, lower rejection rates for the null hypothesis that a coefficient is zero.

${ }^{22}$ With respect to orthogonal deviations transformation, the alternative first-difference transformation magnifies gaps in unbalanced panels, since it subtracts lagged observations from the contemporaneous one. Orthogonal deviations minimize data loss by subtracting the average of all future available observations of a variable. However, we verified that the results are reasonably robust to the choice of transformation.
} 
on bank-level control variables (LTA, NONINT, CAP) are not reported for the sake of brevity, but they are in line with the baseline estimations of Section 5.1.

In line with the existing literature on the macroeconomic determinants of bank lending, GDP growth ( $\Delta$ GDP) has positive and statistically significant coefficients, which is coherent with banks increasing their loans during period of economic expansions. At the same time, in full democracies the positive and strongly significant coefficient on the ELECT dummy reveals higher bank lending in election years. In part, this may reflect the fact that the lending behavior of private banks is also possibly influenced by the power of government.

More importantly, in system GMM estimations the coefficient on the interaction term $\operatorname{ELECT}_{c, t} \cdot D B_{i}$ is negative and significant (at the 5 percent level) in full democracies when considering the size class of smaller development banks (column 6). This evidence not only rejects the political view of development banks, but rather it seems to suggest a lower lending activity of small development banks in periods of political uncertainty. By contrast, the coefficient on $E L E C T_{c, t} \cdot D B_{i}$ is still strongly positive and significant in flawed democracies when considering the size class of larger development banks (column 9), consequently confirming the opportunistic preelectoral behavior of some development banks in countries with lower institutional quality.

In order to determine the appropriateness of our GMM estimations, we report the results of two main tests. The first test examines the hypothesis that the error term is not second-order serially correlated (the error term of the transformed equation is expected to be first-order serially correlated by construction). We introduce two lags of the dependent variables $(j=2)$, since this is the model specification that permits to obtain the lowest $p$-value of the $\mathrm{AR}(2)$ test. 
The second test is a 'difference-in-Sargan/Hansen' test used to examine the validity of subsets of instruments, under the null of joint validity of the full instrument set. Specifically, we report the Sargan/Hansen statistics referring to the system GMM instruments for the levels equation based on first-differences in the dependent variable (i.e. on lagged loans growth). The impossibility to reject the orthogonality conditions for this subset of instruments give support to the system GMM estimator with respect to the difference GMM estimator.

Overall, the estimates of this section confirm that our main results are robust to the adoption of alternative measures of the relevant variables and to different econometric procedures. In particular, the GMM dynamic panel procedures comprehensively confront problems induced by the use of lagged dependent variables and bank-specific effects. Furthermore, GMM dynamic panel estimators use instruments that are 'internal' (i.e. based on lags of the instrumented variables) and that are consequently useful when there are no good 'external' instruments to control the likely endogeneity of the explanatory variables. 
Table 8 - Dynamic model: subsample regressions by DEMOC levels

Dependent variable: Change in Loans ( $\triangle$ LOANS)

\begin{tabular}{|c|c|c|c|c|c|c|c|c|c|}
\hline \multicolumn{10}{|c|}{ Full democracies $(\mathrm{DEMOC}=10)$} \\
\hline & \multicolumn{3}{|c|}{ Whole Sample } & \multicolumn{3}{|c|}{ Smaller DBs' size class } & \multicolumn{3}{|c|}{ Larger DBs' size class } \\
\hline & $\begin{array}{c}\text { Pooled } \\
\text { OLS } \\
\text { (1) }\end{array}$ & $\begin{array}{c}\text { FE } \\
\text { OLS } \\
(2)\end{array}$ & $\begin{array}{c}\text { System } \\
\text { GMM } \\
\text { (3) }\end{array}$ & $\begin{array}{c}\text { Pooled } \\
\text { OLS } \\
\text { (4) }\end{array}$ & $\begin{array}{c}\text { FE } \\
\text { OLS } \\
(5)\end{array}$ & $\begin{array}{c}\text { System } \\
\text { GMM } \\
\text { (6) }\end{array}$ & $\begin{array}{c}\text { Pooled } \\
\text { OLS } \\
\text { (7) }\end{array}$ & $\begin{array}{c}\text { FE } \\
\text { OLS } \\
(8)\end{array}$ & $\begin{array}{c}\text { System } \\
\text { GMM } \\
\text { (9) }\end{array}$ \\
\hline$\triangle$ LOANS(-1) & $\begin{array}{l}0.26^{* * *} \\
{[0.01]}\end{array}$ & $\begin{array}{l}0.13^{* * *} \\
{[0.01]}\end{array}$ & $\begin{array}{l}0.28^{* * *} \\
{[0.01]}\end{array}$ & $\begin{array}{l}0.25^{* * *} \\
{[0.01]}\end{array}$ & $\begin{array}{l}0.13^{* * *} \\
{[0.01]}\end{array}$ & $\begin{array}{l}0.28^{* * *} \\
{[0.02]}\end{array}$ & $\begin{array}{l}0.30^{* * *} \\
{[0.03]}\end{array}$ & $\begin{array}{l}0.18^{* * *} \\
{[0.03]}\end{array}$ & $\begin{array}{l}0.33^{* * *} \\
{[0.03]}\end{array}$ \\
\hline$\triangle$ LOANS(-2) & $\begin{array}{l}0.17^{* * *} \\
{[0.01]}\end{array}$ & $\begin{array}{l}0.07^{* * *} \\
{[0.01]}\end{array}$ & $\begin{array}{l}0.15^{* * *} \\
{[0.01]}\end{array}$ & $\begin{array}{l}0.17^{* * *} \\
{[0.01]}\end{array}$ & $\begin{array}{l}0.07^{* * * *} \\
{[0.01]}\end{array}$ & $\begin{array}{l}0.16^{* * *} \\
{[0.01]}\end{array}$ & $\begin{array}{l}0.17^{* * *} \\
{[0.03]}\end{array}$ & $\begin{array}{l}0.07^{* * *} \\
{[0.03]}\end{array}$ & $\begin{array}{l}0.17^{* * *} \\
{[0.03]}\end{array}$ \\
\hline$\Delta \mathrm{GDP}$ & $\begin{array}{l}0.60^{* * *} \\
{[0.04]}\end{array}$ & $\begin{array}{l}0.82^{* * *} \\
{[0.05]}\end{array}$ & $\begin{array}{l}0.39^{* * *} \\
{[0.08]}\end{array}$ & $\begin{array}{l}0.66^{* * *} \\
{[0.05]}\end{array}$ & $\begin{array}{l}0.93^{* * *} \\
{[0.06]}\end{array}$ & $\begin{array}{l}0.57^{* * *} \\
{[0.08]}\end{array}$ & $\begin{array}{l}0.48^{* * *} \\
{[0.09]}\end{array}$ & $\begin{array}{l}0.55^{* * *} \\
{[0.12]}\end{array}$ & $\begin{array}{c}0.21 \\
{[0.16]}\end{array}$ \\
\hline$\Delta \mathrm{GDP} * \mathrm{DB}$ & $\begin{array}{l}-0.26^{* *} \\
{[0.13]}\end{array}$ & $\begin{array}{l}-0.41^{* *} \\
{[0.20]}\end{array}$ & $\begin{array}{l}-0.21 \\
{[0.19]}\end{array}$ & $\begin{array}{c}-0.53^{* * * *} \\
{[0.18]}\end{array}$ & $\begin{array}{l}-0.55^{*} \\
{[0.32]}\end{array}$ & $\begin{array}{l}-0.71^{* *} \\
{[0.28]}\end{array}$ & $\begin{array}{l}-0.15 \\
{[0.17]}\end{array}$ & $\begin{array}{l}-0.39^{* *} \\
{[0.18]}\end{array}$ & $\begin{array}{l}-0.12 \\
{[0.18]}\end{array}$ \\
\hline ELECT & $\begin{array}{l}1.68^{* * *} \\
{[0.18]}\end{array}$ & $\begin{array}{l}1.69^{* * *} \\
{[0.16]}\end{array}$ & $\begin{array}{l}1.52^{* * *} \\
{[0.20]}\end{array}$ & $\begin{array}{l}2.00^{* * *} \\
{[0.20]}\end{array}$ & $\begin{array}{l}2.05^{* * *} \\
{[0.18]}\end{array}$ & $\begin{array}{l}1.92^{* * *} \\
{[0.24]}\end{array}$ & $\begin{array}{l}1.26^{* * *} \\
{[0.46]}\end{array}$ & $\begin{array}{l}1.19^{* * * *} \\
{[0.44]}\end{array}$ & $\begin{array}{l}1.35^{* * *} \\
{[0.47]}\end{array}$ \\
\hline ELECT * DB & $\begin{array}{c}0.76 \\
{[0.77]}\end{array}$ & $\begin{array}{c}-0.46 \\
{[1.18]}\end{array}$ & $\begin{array}{l}-2.97^{* *} \\
{[1.39]}\end{array}$ & $\begin{array}{c}-0.47 \\
{[1.14]}\end{array}$ & $\begin{array}{c}-0.06 \\
{[1.76]}\end{array}$ & $\begin{array}{l}-5.15^{* *} \\
{[2.10]}\end{array}$ & $\begin{array}{c}1.24 \\
{[1.09]}\end{array}$ & $\begin{array}{c}-0.86 \\
{[1.29]} \\
\end{array}$ & $\begin{array}{c}0.17 \\
{[1.32]}\end{array}$ \\
\hline $\begin{array}{l}\text { Bank controls } \\
\text { Year dummies }\end{array}$ & $\begin{array}{l}\text { YES } \\
\text { YES }\end{array}$ & $\begin{array}{l}\text { YES } \\
\text { YES }\end{array}$ & $\begin{array}{l}\text { YES } \\
\text { YES }\end{array}$ & $\begin{array}{l}\text { YES } \\
\text { YES }\end{array}$ & YES & YES & YES & $\begin{array}{l}\text { YES } \\
\text { YES }\end{array}$ & $\begin{array}{l}\text { YES } \\
\text { YES }\end{array}$ \\
\hline $\begin{array}{l}\text { Year dummies } \\
\text { Obs. }\end{array}$ & $\frac{\text { YES }}{25,810}$ & $\frac{\text { YES }}{25,810}$ & $\frac{\text { YES }}{25,810}$ & $\frac{\text { YES }}{21,096}$ & $\frac{\text { YES }}{21,096}$ & $\frac{\text { YES }}{21,096}$ & $\begin{array}{c}\text { YES } \\
2,758\end{array}$ & $\frac{\text { YES }}{2,758}$ & $\frac{\text { YES }}{2,758}$ \\
\hline $\begin{array}{l}\text { No.individuals } \\
\text { No.instruments }\end{array}$ & & 3,017 & $\begin{array}{c}3,017 \\
97\end{array}$ & & 2,360 & $\begin{array}{c}2,360 \\
97\end{array}$ & & 301 & $\begin{array}{c}301 \\
97\end{array}$ \\
\hline AR2 (p-val) & & & 0.00 & & & 0.00 & & & 0.28 \\
\hline diff.test (p-val) & & & 0.19 & & & 0.04 & & & 0.23 \\
\hline
\end{tabular}

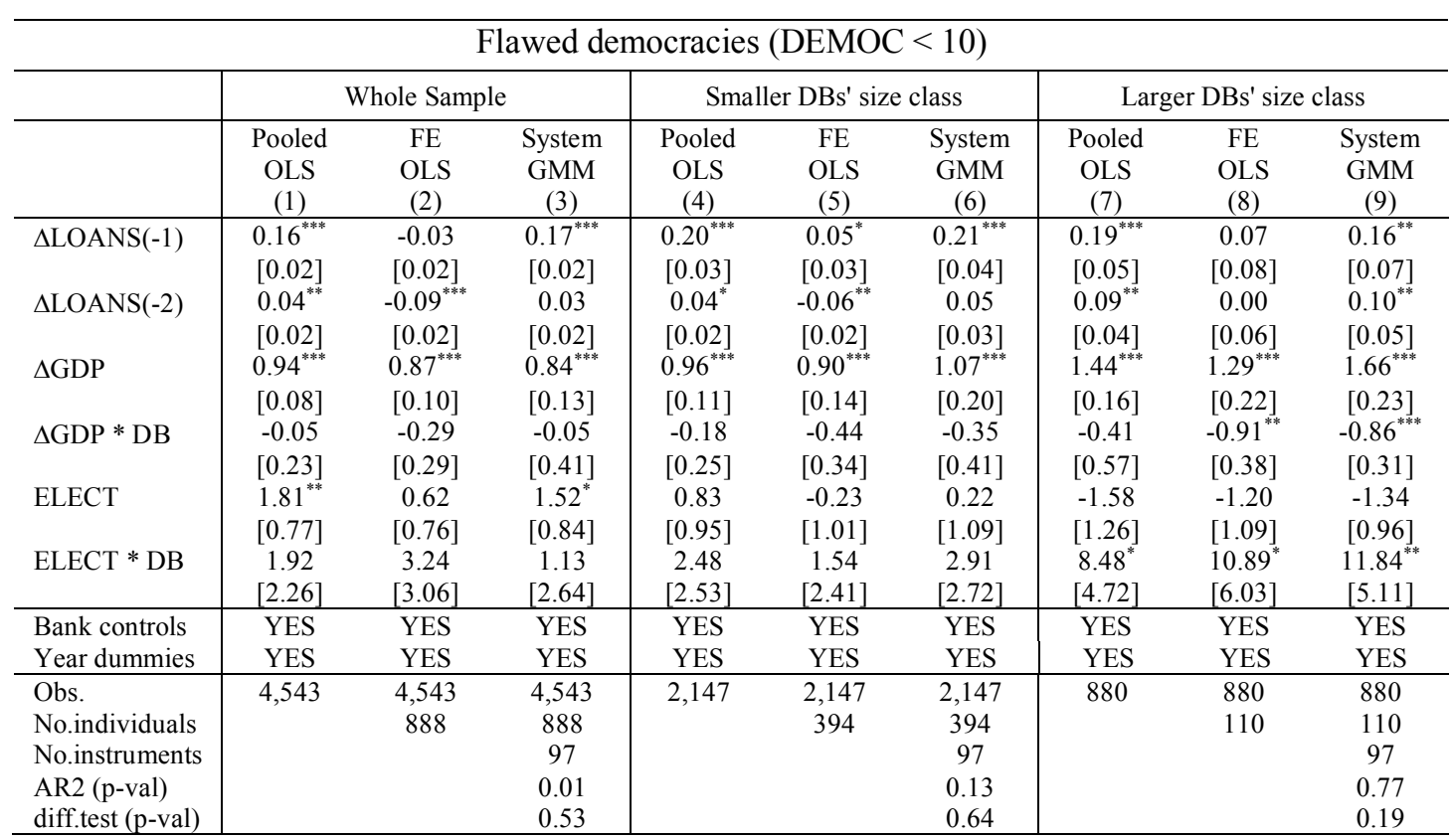

The dependent variable $\Delta$ LOANS measures the change in total loans in year $t$ as a share of total assets in year $t-1$. The model specification includes two lags of the dependent variable - $\Delta$ LOANS(-1) and $\Delta$ LOANS(-2). $\Delta$ GDP is the GDP growth rate by country and year. ELECT is the share of the year $t$ that falls within the twelve months prior to a national election in country $c$. DB is a dummy variable that takes the value of one for development banks. Bank controls include LTA, NONINT and LTA (see Table 7 for descriptions), although the coefficients are not reported for the sake of brevity. Year dummies are included in all regressions. Pooled OLS regressions (columns 1, 4 and 7) and fixed effects OLS regressions (columns 2, 5 and 8 ) use robust standard errors clustered by bank. All system GMM estimates (columns 3, 6 and 9) use two-step GMM estimation with Windmeijer (2005) correction. In GMM estimates, we take $\Delta$ GDP and bank-specific variables to be predetermined - meaning that current values of these variables can be correlated with past and current error terms but not with future error terms. $\operatorname{AR}(2)$ (p-val) is the p-value of Arellano-Bond test for second order autocorrelated disturbances in first differences. Diff.test ( $\mathrm{p}$-val) is the p-value of the difference-in-Sargan/Hansen test referring to the system GMM instruments for the levels equation based on first-differences in the dependent variable.

Significance levels: ${ }^{*} p<0.1,{ }^{* *} p<0.05,{ }^{* * *} p<0.01$ 


\section{Conclusions}

Misallocation of investments due to political interference has historically been one of the major concerns related to the action of state-owned banks. Our paper is the first to analyze the issue for all development banks headquartered in Europe, whose strategic role in catalyzing long-term finance and implementing EU policies has come to light after the 2008 crisis.

Empirical findings point out that, overall, European development banks are not necessarily politically influenced, in the sense that they do not modify their lending activity during electoral years, which is the variable traditionally used to proxy the issue. From a policy point of view, these findings suggest that providing financial funds to development banks does not necessarily lead to an inappropriate use of public resources. Moreover, evidence of counter-cyclical stance in their lending activity confirms the beneficial role played by development banks in periods of economic slowdown.

These encouraging results are in line with a growing body of literature on contemporary state-owned enterprises that reveals the significant positive changing dynamics that have shaped their contemporary features and roles, such as greater transparency and accountability, better compliance with ethical and deontological requirements and strengthening in corporate governance rules and regulatory frameworks (Bernier et al. 2019; Karolyi and Liao, 2017; Musacchio and Lazzarini, 2014; Bruton et al., 2015; Clò et al., 2017; Cuervo-Cazurra et al., 2014).

However, we also find that the lending behavior of development banks under election years differs in countries with distinct institutional settings, revealing that an opportunistic pre-electoral behavior of development banks is more likely to materialize in countries with lower levels of democratic development. In fact, while there is no 
evidence that politicians use development banks for electoral purposes in full democracies, there is some clear signal that large development banks in flawed democracies actually increase lending around elections at a statistically significant percentage more than the rest of the banking system, thus revealing the role played by politics in their lending decisions.

We suggest that European policy makers should carefully consider these empirical evidences, given the role attributed to development banks in their contemporary agenda. Our results lead to think carefully about the role of legal and political institutions for a proper functioning of development banks and defenses against the distortions possibly arising from government ownership, although we are aware that other factors may have a role, such as the fact that market failures are less severe in more developed countries and alternative channels become available for the governments to support the economy (e.g. take-or-pay joint ventures and other types of public-private partnerships). Results also add to existing literature on the importance of institutional quality for the economic development and on its different impact on public and private enterprises. ${ }^{23}$

Finally, differences in the quality of development banks' governance need to be further explored. Professional management, sound risk management, internal control procedures, and the degree of independence are indeed key issues for the governance mechanism to remain free from political interference. Indeed, the absence of politically motivated lending in countries with higher institutional quality could be justified not only by the lower influence exerted by governments, but also by the better internal governance of development banks, reflecting the nationwide external governance. This awareness suggests interesting further development of future research.

\footnotetext{
${ }^{23}$ For an in-depth analysis about the relationship between the quality of institutions and firm's productivity, see Efendic et al. (2011) and Driffield et al. (2013). On the different impact on public and private enterprises see Castelnovo et al. (2018).
} 


\section{References}

Ades, A., Di Tella, R.D.,1997. National champions and corruption: some unpleasant interventionist arithmetic. Economic Journal, 107(443), 1023-1042.

Altunbas, Y., Marques, D., 2008. Mergers and acquisitions and bank performance in Europe. The role of strategic similarities. Journal of Economics and Business 60, 204-222.

Arellano, M., Bond, S., 1991. Some tests of specification for panel data: Monte Carlo evidence and an application to employment equations. Review of Economic Studies $58,277-297$.

Arellano, M., Bover, O., 1995. Another look at the instrumental-variable estimation of error components models. Journal of Econometrics 68, 29-52.

Bacchiocchi, E., Ferraris, M., Florio, M., Vandone, D., 2017. State-owned banks in the market for corporate control. Journal of Economic Policy Reform, 1-28.

Barth, J.R., Caprio, G. Jr., Levine, R., 1999. Banking Systems Around the Globe: Do Regulation and Ownership Affect Performance and Stability? Working Paper 2325, World Bank.

Beck, T., Levine, R., 2002. Industry Growth and Capital Allocation: Does Having a Market- or Bank Based System Matter? Journal of Financial Economics 64, 147180.

Berger, A.N., Clarke, G.R.G., Cull, R., Klapper, L., Udell, G.F., 2005. Corporate governance and bank performance: A joint analysis of the static, selection, and dynamic effects of domestic, foreign, and state ownership. Journal of Banking \& Finance 29(8), 2179-2221.

Bernier, L., Florio, M., Bance, P., 2019. Handbook of State-Owned Enterprises. Routledge (forthcoming). 
Bertoni, F., Tykvová, T., 2015. Does governmental venture capital spur invention and innovation? Evidence from young European biotech companies, Research Policy 44(4), 925-935.

Bleda, M., Del Rio, P., 2013. The market failure and the systemic failure rationales in technological innovation systems. Research Policy, 42(5), 1039-1052.

Blundell, R., Bond, S., 1998. Initial conditions and moment restrictions in dynamic panel data models. Journal of Econometrics 87, 115-143.

Bruton, G., Peng, M., Ahlstrom, D., Stan, C., Xu K., 2015. State-owned enterprises around the world as hybrid organizations, Academy of Management Perspectives 29(1), 92-114.

Castelnovo, P., Del Bo, C., Florio, M., 2018. Quality of institutions and productivity of State-Invested Enterprises: international evidence from major telecom companies. European Journal of Political Economy. In press.

Chakravarty, S.P., Williams, J.M., 2006. How significant is the alleged unfair advantage enjoyed by state-owned banks in Germany? Cambridge Journal of Economics 30(2), 219-226.

Claessens, S., Feijen, E., Leaven L., 2008. Political connections and preferential access to finance: the role of campaign contributions. Journal of Financial Economics, $88(3), 554-580$.

Clifton, J., Díaz-Fuentes, D., Revuelta, J., 2014. Financing utilities: How the role of the European Investment Bank shifted from regional development to making markets. Utilities Policy 29, 63-71.

Clifton, J., Díaz-Fuentes, D., Gómez, A. L., 2018. The European Investment Bank: Development, Integration, Investment?. Journal of Common Market Studies, 56(4), 733-750. 
Clò, S., Fiorio, C., Florio, M., 2017. The targets of state capitalism: evidence from M\&A deals. European Journal of Political Economy 47, 61-74

Cornett, M.M., Guo, L., Khaksari, S., Tehranian, H., 2010. The impact of state ownership on performance differences in privately-owned versus state-owned banks: An international comparison. Journal of Financial Intermediation 19(1), 7494.

Cruz, C., Keefer, P., Scartascini, C., 2018. Database of Political Institutions 2017 (DPI2017). Inter-American Development Bank. Numbers for Development. https://mydata.iadb.org/Reform-Modernization-of-the-State/Database-of-PoliticalInstitutions-2017/938i-s2bw

Cuervo-Cazurra, A., Inkpen, A., Musacchio, A. Ramaswamy, K., 2014. Governments as owners: State-owned multinational companies. Journal of International Business Studies 4(8), 919-942.

De Aghion, B. A., 1999. Development banking. Journal of Development Economics $58(1), 83-100$.

De Olloqui, F., Chrisney, M.D., Lorenzo, J.G., Maffioli, A., Monge-González, R., Netto, M., Nieder, F., Arancibia, P., Palma, C., Rodríguez, C.M., 2013. Public development banks: Toward a new paradigm. Washington, DC: IDB.

Delis, M., Hasan, I., Ongena, S., 2017. Democracy and Credit “Democracy Doesn’t Come Cheap" But At Least Credit to Its Corporations Will Be (No. 17-14). Swiss Finance Institute.

Diamond, W., 1957. Development Banks. The Economic Development Institute. Baltimore: The Johns Hopkins Press.

Dinç, I.S., 2005. Politicians and banks: Political influences on government-owned banks in emerging markets. Journal of Financial Economics 77(2), 453-479. 
Drazen, A., 2000. The political business cycle after 25 years. NBER Macroeconomics Annual 15, 75-117.

Dreher, A., Vaubel, R., 2004. Do IMF and IBRD cause moral hazard and political business cycles? Evidence from panel data. Open economies review, 15(1), 5-22.

Dreher, A., Vaubel, R., 2009. Foreign exchange intervention and the political business cycle: A panel data analysis. Journal of International Money and Finance 28(5), 755775.

Driffield, N., Michiewicz, T., Tomouri Y., 2013. Institutional reforms, productivity and profitability: from rents to competition? Journal of Comparative Economics 41(2), 583-600.

Efendic, A., Pugh, G., Adnett, N., 2011. Institutions and economic performance: a meta-regression analysis. European Journal of Political Economy 27(3), 586-599.

Eslava, M., Freixas, W., 2016. Public Development Banks and credit market imperfections. Documentos CIDE n.6.

European Commission, 2014. An Investment Plan for Europe. Communication from the Commission to the European Parliament, the Council, the European Central Bank, the European Economic and Social Committee, the Committee of the Regions and the European Investment Bank. COM(2014)903 final, Brussels.

European Commission, 2015a. Investment dynamics in the euro area since the crisis. Quarterly Report on the Euro Area 14(1), 35-43. DG ECFIN

European Commission, 2015b. Working together for jobs and growth: The role of National Promotional Banks (NPBs) in supporting the Investment Plan for Europe. Communication from the Commission to the European Parliament and the Council, COM(2015) 361 final, Brussels. 
European Commission, 2018. Financing a sustainable European economy, final report by the High-Level Expert Group on Sustainable Finance

European Parliament, 2016. New Financial Instruments and the Role of National Promotional Banks. DG IPOL Study.

Foray, D., Mowery, D.C., Nelson, R.R., 2012. Public R\&D and societal challenges: what lessons from mission R\&D programs? Research Policy 41, 1697-1702.

Gonzalez, M., 1999. On elections, democracy and macroeconomic policy cycles. Department of Economics, Princeton University. Working Paper.

Griffith-Jones, S., Tyson, Y., 2013. The European Investment Bank: Lessons for Developing Countries. UNU-WIDER Working Paper 2013/019, United Nation University.

Gutierrez, E., Rudolph, H.P., Homa, T., Beneit, E.B., 2011. Development banks: role and mechanisms to increase their efficiency. World Bank Policy Research Working Paper Series, 5729. Washington, DC: World Bank.

Hansen, L.P., 1982. Large sample properties of generalized method of moments estimators. Econometrica 50: 1029-1054.

Hart, O., Shleifer, A., Vishny, R.W., 1997. The proper scope of government: theory and an application to prisons. The Quarterly Journal of Economics 112(4), 11271161.

Holtz-Eakin, D., Newey, W., Rosen, H., 1988. Estimating vector autoregressions with panel data. Econometrica 56, 1371-1395.

Iannotta, G., Nocera, G., Sironi, A., 2007. Ownership structure, risk and performance in the European banking industry. Journal of Banking \& Finance 31, 2127-2149. 
Kalemli-Ozcan, S., Sorensen, B., Villegas-Sanchez, C., Volosovych, V., Yesiltas, S., 2015. How to construct nationally representative firm level data from the ORBIS global database (No. w21558). National Bureau of Economic Research.

Karolyi, A.G., Liao, R.C., 2017. State capitalism's global reach: Evidence from foreign acquisitions by state-owned companies, Journal of Corporate Finance 47, 367-391.

Kaufmann, D., Kraay, A., Mastruzzi, M., 2010. The Worldwide Governance Indicators: A Summary of Methodology, Data and Analytical Issues. World Bank Policy Research Working Paper No. 5430.

KfW et al., 2016. France, Germany, Italy, Spain and the United Kingdom - Building Momentum in Venture Capital across Europe, Kreditanstalt für Wiederaufbau Bankengruppe, Frankfurt am Main.

Khwaja, A., Mian, A., 2005. Do lenders favor politically connected firms? Rent provision in an emerging financial market. Quarterly Journal of Economics 120(4), $1371-1411$.

Kornai, J., 1979. Resource-constrained versus demand-constrained systems. Econometrica 47, 801-819.

La Porta, R., Lopez-de-Silanes, F., Shleifer, A., 2002. Government ownership of banks. The Journal of Finance 57(1), 265-301.

Lazzarini, S., Musacchio, A., Bandeire-De-Mello, R., Marcon, R., 2015. What do stateowned development banks do? Evidence from BNDES, 2002-2009. World Development 66, 237-253.

Lin, J.Y., Tan G., 1999. Policy burdens, accountability, and the soft budget constraint. American Economic Review, 89(2), 426-431.

de Luna-Martinez, J., Vicente, C., 2012. Global survey of development banks. World Bank Policy Research Working Paper, 5969. Washington, DC: World Bank. 
Mazzuccato, M., Penna, C.C.R., 2016. Beyond market failures: The market creating and shaping roles of state investment banks. Journal of Economic Policy Reform 19(4), 305-326.

Mertens, D., Thiemann, M., 2019. Building a hidden investment state? The European Investment Bank, national development banks and European economic governance. Journal of European Public Policy 26(1), 23-43.

Micco, A., Panizza, U., Yanez, M., 2007. Bank ownership and performance. Does politics matter? Journal of Banking \& Finance 31(1), 219-241.

Musacchio, A., Lazzarini, S.B., 2014. Reinventing State Capitalism. Leviathan in Business, Brazil and Beyond. Cambridge (Mass.) and London: Harvard University Press.

Nickell, S.J., 1981. Biases in dynamic models with fixed effects. Econometrica 49, $1417-1426$.

Nordhaus, W.D., 1975. The political business cycle. The Review of Economic Studies, 42(2), 169-190.

OECD, 2018. Making Blended Finance Work for the Sustainable Development Goals, OECD Publishing, Paris.

Roodman, D., 2009. A note on the theme of too many instruments. Oxford Bulletin of Economics and Statistics 71, 135-158.

Sapienza, P., 2004. The effects of government ownership on bank lending, Journal of Financial Economics 72(2), 357-384.

Schmit, M., Denuit, T., Gheeraert, L., Warny, C., 2011. Roles, Missions and Business Models of Public Financial Institutions in Europe (No. 2011/5). SUERF Studies.

Schuknecht, L., 1996. Political business cycles in developing countries. Kyklos 49, $155-170$. 
Shi, M., Svensson, J., 2002. Political budget cycles: Do they differ across countries and why? Journal of Public Economics, 90(8-9), 1367-1389.

Shleifer, A., Vishny, R.W., 1994. Politicians and firms. Quarterly Journal of Economics 109(4), 995-1025.

Shleifer, A., Vishny, R.W., 1997. A survey of corporate governance. Journal of Finance 52(2), 737-783.

Tuijnman, A., 2009. The education lending policy of the European Investment Bank. European Journal of Education 44(1), 111-125.

Windmeijer, F., 2005. A finite sample correction for the variance of linear efficient two-step GMM estimators. Journal of Econometrics 126, 25-51.

World Bank, 2018. Survey of national development banks, Global Report, May.

Yeyati, E.L., Micco, A., 2003. Banking competition in Latin America. In Latin American Competition Forum.

Yeyati, E.L., Micco, A., Panizza, U., 2004. Should the government be in the banking business? The role of state-owned and development banks. Research Working Paper 517, Washington: Inter-American Development Bank.

Yeyati E.L., Micco, A., Panizza, U., Detragiache, E., Repetto, A., 2007. A reappraisal of State-Owned Banks. Economía 7(2), 209-259.

Yildirim, H.S., Philippatos, G., 2007. Efficiency of Banks: Recent Evidence from the Transition Economies of Europe, 1993-2000. The European Journal of Finance $13(2), 123-143$. 


\section{Appendix}

Table A.1 - Sample statistics

\begin{tabular}{|c|c|c|c|c|c|c|c|c|c|c|}
\hline & & \multicolumn{3}{|c|}{ All countries } & \multicolumn{3}{|c|}{$\begin{array}{l}\text { Full Democracies } \\
(\text { DEMOC }=10)\end{array}$} & \multicolumn{3}{|c|}{$\begin{array}{c}\text { Flawed Democracies } \\
(\text { DEMOC }<10)\end{array}$} \\
\hline & & Banks & DBs & & Banks & DBs & & Banks & DBs & \\
\hline \multirow[t]{3}{*}{ TA } & Mean & 8.936 & 27.333 & $* * *$ & 7.956 & 28.461 & $* * *$ & 13.386 & 24.214 & \\
\hline & s.d. & 81.691 & 71.556 & & 73.207 & 75.157 & & 112.324 & 60.551 & \\
\hline & $N$ & 39,444 & 757 & & 32,324 & 556 & & 7,120 & 201 & \\
\hline \multirow[t]{3}{*}{$\triangle \mathrm{LOANS}$} & Mean & 3.402 & 4.517 & $* * *$ & 2.897 & 3.707 & $* * *$ & 5.696 & 6.756 & \\
\hline & s.d. & 8.043 & 9.668 & & 6.082 & 8.410 & & 13.567 & 12.255 & \\
\hline & $N$ & 39,444 & 757 & & 32,324 & 556 & & 7,120 & 201 & \\
\hline \multirow[t]{3}{*}{ LOANS } & Mean & 57.650 & 47.589 & $* * *$ & 58.794 & 48.118 & $* * *$ & 52.455 & 46.123 & $* * *$ \\
\hline & s.d. & 17.468 & 25.965 & & 16.555 & 26.726 & & 20.328 & 23.735 & \\
\hline & $N$ & 39,444 & 757 & & 32,324 & 556 & & 7,120 & 201 & \\
\hline \multirow[t]{3}{*}{ CAP } & Mean & 10.664 & 18.784 & $* * *$ & 9.159 & 17.831 & $* * *$ & 18.608 & 21.421 & $* * *$ \\
\hline & s.d. & 8.420 & 17.863 & & 6.413 & 18.676 & & 12.924 & 15.123 & \\
\hline & $N$ & 39,444 & 757 & & 33,787 & 556 & & 7,120 & 201 & \\
\hline \multirow[t]{3}{*}{ NONINT } & Mean & 2.442 & 1.744 & $* * *$ & 1.150 & 1.736 & $* * *$ & 8.305 & 1.764 & $* * *$ \\
\hline & s.d. & 5.311 & 3.725 & & 1.970 & 4.136 & & 9.835 & 2.227 & \\
\hline & $N$ & 39,444 & 757 & & 32,324 & 556 & & 7,120 & 201 & \\
\hline \multirow[t]{3}{*}{ INTINC } & Mean & 5.337 & 5.280 & & 4.347 & 4.621 & $* * *$ & 9.866 & 7.098 & $* * *$ \\
\hline & s.d. & 3.079 & 3.257 & & 1.398 & 2.610 & & 4.349 & 4.076 & \\
\hline & $N$ & 39,243 & 755 & & 32,204 & 554 & & 7,039 & 201 & \\
\hline \multirow[t]{3}{*}{ OPEX } & Mean & 3.931 & 1.752 & $* * *$ & 2.484 & 1.508 & $* * *$ & 10.513 & 2.426 & $* * *$ \\
\hline & s.d. & 5.644 & 2.389 & & 1.877 & 2.362 & & 10.386 & 2.339 & \\
\hline & $N$ & 39,332 & 756 & & 32,242 & 555 & & 7,090 & 201 & \\
\hline
\end{tabular}

DBs denote the subsample of development banks, while Banks denotes the rest of the banks included in the sample. TA is total assets in EUR billions. $\Delta$ LOANS measures the change in total loans in year $t$ as a share of total assets in year $t-1$. LOANS measures total loans as a share of total assets. CAP measures total equity as a share of total assets. NONINT measures non-interest income as a share of average total assets. INTINC measures interest income as a share of average interest earning assets (i.e. the average of earning assets at the beginning of the year and at the year's end). OPEX measures operating expenses as a share of average total assets.

${ }^{*},{ }^{* *}$, and ${ }^{* * *}$ denote statistical significance at the $10 \%, 5 \%$, and $1 \%$ levels, respectively, in a two-sided test of the mean with the Bank sample and the DBs sample. 
Table A.2 - Elections and lending activity: triple interaction term Dependent variable: Change in Loans ( $\triangle$ LOANS)

\begin{tabular}{|c|c|c|c|}
\hline & $\begin{array}{c}\text { Whole Sample } \\
\text { (1) }\end{array}$ & $\begin{array}{c}\text { Smaller DBs' size class } \\
(2)\end{array}$ & $\begin{array}{l}\text { Larger DBs' size class } \\
\text { (3) }\end{array}$ \\
\hline LTA & $\begin{array}{c}-3.65^{* * *} \\
{[0.40]}\end{array}$ & $\begin{array}{c}-4.79^{* * *} \\
{[0.42]}\end{array}$ & $\begin{array}{c}-4.43^{* * *} \\
{[0.86]}\end{array}$ \\
\hline NONINT & $\begin{array}{l}-0.00 \\
{[0.01]}\end{array}$ & $\begin{array}{c}0.01 \\
{[0.02]}\end{array}$ & $\begin{array}{c}0.08 \\
{[0.13]}\end{array}$ \\
\hline CAP & $\begin{array}{l}-0.01 \\
{[0.02]}\end{array}$ & $\begin{array}{l}-0.01 \\
{[0.03]}\end{array}$ & $\begin{array}{l}-0.11^{*} \\
{[0.06]}\end{array}$ \\
\hline$\Delta \mathrm{GDP} * \mathrm{DB}$ & $\begin{array}{c}-0.46^{* * *} \\
{[0.14]}\end{array}$ & $\begin{array}{l}-0.40^{* *} \\
{[0.19]}\end{array}$ & $\begin{array}{c}-0.45^{* * *} \\
{[0.17]}\end{array}$ \\
\hline$\Delta \mathrm{GDP} * \mathrm{DB} * \mathrm{FLAWED}$ & $\begin{array}{c}0.13 \\
{[0.22]}\end{array}$ & $\begin{array}{c}0.04 \\
{[0.23]}\end{array}$ & $\begin{array}{l}-0.84^{*} \\
{[0.45]}\end{array}$ \\
\hline ELECT $*$ DB & $\begin{array}{l}-1.08 \\
{[0.92]}\end{array}$ & $\begin{array}{c}-0.46 \\
{[1.42]}\end{array}$ & $\begin{array}{l}-1.01 \\
{[1.33]}\end{array}$ \\
\hline ELECT $*$ DB $*$ FLAWED & $\begin{array}{l}3.86^{*} \\
{[2.10]}\end{array}$ & $\begin{array}{c}1.75 \\
{[2.33]}\end{array}$ & $\begin{array}{l}9.08^{* *} \\
{[4.03]}\end{array}$ \\
\hline Bank fixed effects & YES & YES & YES \\
\hline Country-Year effects & YES & YES & YES \\
\hline $\begin{array}{l}\text { Observations } \\
\text { N. of countries } \\
\text { r2 }\end{array}$ & $\begin{array}{c}40,201 \\
27 \\
0.27\end{array}$ & $\begin{array}{c}29,928 \\
27 \\
0.30\end{array}$ & $\begin{array}{c}4,650 \\
24 \\
0.46\end{array}$ \\
\hline
\end{tabular}

The regression is run within separate size classes: (i) the whole sample (column 1); (ii) the smaller DB's size class (column 2), which includes banks in the percentiles $22-90$ by total assets; (iii) the larger DBs' size class (column 3), which includes banks above the 90th percentile (see Section 3.1 for details). The dependent variable $\Delta$ LOANS measures the change in total loans in year $t$ as a share of total assets in year $t-1$. LTA is the logarithm of lagged total assets in EUR thousands. NONINT is the lagged share of noninterest income over average total assets (i.e. the average of total assets at the beginning of the year and at the year's end). CAP is the lagged share of total equity over total assets. $\triangle$ GDP is the GDP growth rate by country and year. ELECT is the share of the year $t$ that falls within the twelve months prior to a national election in country $c$. DB is a dummy variable that takes the value of one for development banks. FLAWED is a dummy variable that takes the value of one for "flawed democracies", i.e. countries that in a given year have not the maximum level (10) of constitutional democratic development (DEMOC), measured by the Polity IV Project. Then, a significant coefficient on ELECT * DB * FLAWED means that ELECT * DB is significantly higher in flawed democracies than in full democracies. The reference period is 2002-2015. Robust standard errors in brackets.

Significance levels: ${ }^{*} p<0.1,{ }^{* *} p<0.05,{ }^{* * *} p<0.01$ 
Table A.3 - Elections and lending activity: adopting a weighting strategy

Dependent variable: Change in Loans ( $\triangle$ LOANS)

\begin{tabular}{|c|c|c|c|}
\hline & $\begin{array}{l}\text { All countries } \\
\text { (1) }\end{array}$ & $\begin{array}{c}\text { Full democracies } \\
(\mathrm{DEMOC}=10) \\
(2)\end{array}$ & $\begin{array}{c}\text { Flawed democracies } \\
(\text { DEMOC }<10) \\
(3)\end{array}$ \\
\hline LTA & $\begin{array}{l}-1.68^{*} \\
{[0.96]}\end{array}$ & $\begin{array}{c}-1.20 \\
{[0.95]}\end{array}$ & $\begin{array}{c}-3.74 \\
{[2.34]}\end{array}$ \\
\hline NONINT & $\begin{array}{l}-0.11 \\
{[0.08]}\end{array}$ & $\begin{array}{l}-0.01 \\
{[0.10]}\end{array}$ & $\begin{array}{l}-0.22^{* * *} \\
{[0.08]}\end{array}$ \\
\hline CAP & $\begin{array}{c}0.05 \\
{[0.06]}\end{array}$ & $\begin{array}{c}0.04 \\
{[0.08]}\end{array}$ & $\begin{array}{c}0.01 \\
{[0.12]}\end{array}$ \\
\hline$\Delta \mathrm{GDP} * \mathrm{DB}$ & $\begin{array}{c}-0.58^{* * *} \\
{[0.19]}\end{array}$ & $\begin{array}{l}-0.37^{* *} \\
{[0.18]}\end{array}$ & $\begin{array}{l}-1.32^{* * *} \\
{[0.31]}\end{array}$ \\
\hline ELECT $*$ DB & $\begin{array}{c}0.37 \\
{[1.03]}\end{array}$ & $\begin{array}{c}0.65 \\
{[1.43]}\end{array}$ & $\begin{array}{l}4.20^{* * * *} \\
{[1.19]}\end{array}$ \\
\hline $\begin{array}{l}\text { Bank fixed effects } \\
\text { Country-Year effects }\end{array}$ & $\begin{array}{l}\text { YES } \\
\text { YES }\end{array}$ & $\begin{array}{l}\text { YES } \\
\text { YES }\end{array}$ & $\begin{array}{l}\text { YES } \\
\text { YES } \\
\end{array}$ \\
\hline $\begin{array}{l}\text { Observations } \\
\text { N. of countries } \\
\text { r2 }\end{array}$ & $\begin{array}{c}40,201 \\
27 \\
0.44 \\
\end{array}$ & $\begin{array}{c}32,880 \\
17 \\
0.41 \\
\end{array}$ & $\begin{array}{c}7,321 \\
13 \\
0.53 \\
\end{array}$ \\
\hline
\end{tabular}

In columns 2-3, the sample is split based the level of constitutional democratic development (DEMOC), measured by the Polity IV Project on a zero-to-ten scale, with ten indicating "full democracy" and lower levels indicating "flawed democracies". Countries are allowed to move from one group to another according to the annual value of DEMOC. All regressions are weighted by the bank's share of lagged total assets in the year. The dependent variable $\triangle$ LOANS measures the change in total loans in year $t$ as a share of total assets in year $t-1$. LTA is the logarithm of lagged total assets in EUR thousands. NONINT is the lagged share of non-interest income over average total assets (i.e. the average of total assets at the beginning of the year and at the year's end). CAP is the lagged share of total equity over total assets. $\triangle$ GDP is the GDP growth rate by country and year. ELECT is the share of the year $t$ that falls within the twelve months prior to a national election in country $c$. DB is a dummy variable that takes the value of one for development banks. The reference period is 2002-2015. Robust standard errors in brackets. Significance levels: ${ }^{*} p<0.1,{ }^{* *} p<0.05,{ }^{* * *} p<0.01$ 
Table A.4 - Elections and lending activity: executive constraints

Dependent variable: Change in Loans ( $\triangle$ LOANS)

\begin{tabular}{|c|c|c|c|c|c|c|}
\hline & \multicolumn{3}{|c|}{$\begin{array}{l}\text { Full Constraints on Chief Executive } \\
(\text { XCONST }=7)\end{array}$} & \multicolumn{3}{|c|}{$\begin{array}{l}\text { Flawed Constraints on Chief Executive } \\
(\text { XCONST }<7)\end{array}$} \\
\hline & $\begin{array}{l}\text { Whole } \\
\text { Sample } \\
\text { (1) }\end{array}$ & $\begin{array}{l}\text { Smaller DBs' } \\
\text { size class } \\
\text { (2) }\end{array}$ & $\begin{array}{l}\text { Larger DBs' } \\
\text { size class } \\
\text { (3) }\end{array}$ & $\begin{array}{c}\text { Whole } \\
\text { Sample } \\
\text { (4) }\end{array}$ & $\begin{array}{l}\text { Smaller DBs' } \\
\text { size class } \\
(5)\end{array}$ & $\begin{array}{c}\text { Larger DBs } \\
\text { size class } \\
(6)\end{array}$ \\
\hline LTA & $\begin{array}{l}-4.24^{* * *} \\
{[0.56]}\end{array}$ & $\begin{array}{c}-5.01^{* * *} \\
{[0.40]}\end{array}$ & $\begin{array}{c}-4.16^{* * *} \\
{[0.93]}\end{array}$ & $\begin{array}{l}-2.79^{* * * *} \\
{[0.58]}\end{array}$ & $\begin{array}{c}-4.20^{* * *} \\
{[1.19]}\end{array}$ & $\begin{array}{c}-5.08^{* * *} \\
{[1.52]}\end{array}$ \\
\hline NONINT & $\begin{array}{l}-0.00 \\
{[0.02]}\end{array}$ & $\begin{array}{c}0.01 \\
{[0.01]}\end{array}$ & $\begin{array}{c}0.05 \\
{[0.11]}\end{array}$ & $\begin{array}{c}-0.00 \\
{[0.01]}\end{array}$ & $\begin{array}{c}0.02 \\
{[0.03]}\end{array}$ & $\begin{array}{l}-0.28 \\
{[0.26]}\end{array}$ \\
\hline CAP & $\begin{array}{l}-0.04 \\
{[0.03]}\end{array}$ & $\begin{array}{l}-0.03 \\
{[0.04]}\end{array}$ & $\begin{array}{l}-0.08 \\
{[0.06]}\end{array}$ & $\begin{array}{c}0.02 \\
{[0.03]}\end{array}$ & $\begin{array}{c}0.03 \\
{[0.06]}\end{array}$ & $\begin{array}{c}0.02 \\
{[0.13]}\end{array}$ \\
\hline$\Delta \mathrm{GDP} * \mathrm{DB}$ & $\begin{array}{c}-0.47^{* * *} \\
{[0.12]}\end{array}$ & $\begin{array}{c}-0.45^{* * *} \\
{[0.18]}\end{array}$ & $\begin{array}{l}-0.41^{* * *} \\
{[0.15]}\end{array}$ & $\begin{array}{l}-0.10 \\
{[0.23]}\end{array}$ & $\begin{array}{l}-0.24 \\
{[0.17]}\end{array}$ & $\begin{array}{l}-1.29^{* * *} \\
{[0.46]}\end{array}$ \\
\hline ELECT * DB & $\begin{array}{l}-0.66 \\
{[0.85]}\end{array}$ & $\begin{array}{l}-0.20 \\
{[1.26]}\end{array}$ & $\begin{array}{l}-0.61 \\
{[1.30]}\end{array}$ & $\begin{array}{l}1.10 \\
{[1.56]}\end{array}$ & $\begin{array}{c}1.67 \\
{[2.18]}\end{array}$ & $\begin{array}{l}4.56^{*} \\
{[2.47]}\end{array}$ \\
\hline $\begin{array}{l}\text { Bank f.e. } \\
\text { Country-year f.e. }\end{array}$ & $\begin{array}{l}\text { YES } \\
\text { YES }\end{array}$ & $\begin{array}{l}\text { YES } \\
\text { YES }\end{array}$ & $\begin{array}{l}\text { YES } \\
\text { YES }\end{array}$ & $\begin{array}{l}\text { YES } \\
\text { YES }\end{array}$ & $\begin{array}{l}\text { YES } \\
\text { YES }\end{array}$ & $\begin{array}{l}\text { YES } \\
\text { YES }\end{array}$ \\
\hline $\begin{array}{l}\text { Observations } \\
\text { N. of countries } \\
\text { r2 }\end{array}$ & $\begin{array}{c}33,916 \\
23 \\
0.26\end{array}$ & $\begin{array}{c}27,337 \\
23 \\
0.28\end{array}$ & $\begin{array}{c}3,718 \\
20 \\
0.41\end{array}$ & $\begin{array}{c}6,285 \\
6 \\
0.28\end{array}$ & $\begin{array}{c}2,591 \\
6 \\
0.35\end{array}$ & $\begin{array}{c}932 \\
6 \\
0.62\end{array}$ \\
\hline
\end{tabular}

The sample is split based the level of Constraints on Chief Executive (XCONST), measured by the Polity IV Project on a zero-to-ten scale, with seven indicating "full constraints" and lower levels indicating "flawed constraints". Countries are allowed to move from one group to another according to the annual value of XCONST. The regression is run within separate size classes: (i) the whole sample (columns 1 and 4); (ii) the smaller DB's size class (columns 2 and 5), which includes banks in the percentiles 22-90 by total assets; (iii) the larger DBs' size class (columns 3 and 6), which includes banks above the 90th percentile (see Section 3.1 for details). The dependent variable $\triangle$ LOANS measures the change in total loans in year $t$ as a share of total assets in year $t-1$. LTA is the logarithm of lagged total assets in EUR thousands. NONINT is the lagged share of non-interest income over average total assets (i.e. the average of total assets at the beginning of the year and at the year's end). CAP is the lagged share of total equity over total assets. $\triangle \mathrm{GDP}$ is the GDP growth rate by country and year. ELECT is the share of the year $t$ that falls within the twelve months prior to a national election in country $c$. DB is a dummy variable that takes the value of one for development banks. The reference period is 2002-2015. Robust standard errors in brackets.

Significance levels: ${ }^{*} p<0.1,{ }^{* *} p<0.05,{ }^{* * *} p<0.01$ 
Table A.5 - Elections and lending activity: geographical division

Dependent variable: Change in Loans ( $\triangle$ LOANS)

\begin{tabular}{|c|c|c|c|c|c|c|}
\hline & \multicolumn{3}{|c|}{ Western Europe } & \multicolumn{3}{|c|}{ Eastern Europe } \\
\hline & $\begin{array}{c}\text { Whole } \\
\text { Sample } \\
\text { (1) }\end{array}$ & $\begin{array}{c}\text { Smaller DBs' } \\
\text { size class } \\
\text { (2) }\end{array}$ & $\begin{array}{c}\text { Larger DBs' } \\
\text { size class } \\
\text { (3) }\end{array}$ & $\begin{array}{c}\text { Whole } \\
\text { Sample } \\
(4)\end{array}$ & $\begin{array}{c}\text { Smaller DBs' } \\
\text { size class } \\
\text { (5) }\end{array}$ & $\begin{array}{c}\text { Larger DBs' } \\
\text { size class } \\
(6)\end{array}$ \\
\hline LTA & $-3.92^{* * *}$ & $-4.86^{* * *}$ & $-3.86^{* * *}$ & $-3.35^{* * *}$ & $-4.64^{* * * *}$ & $-8.30^{* * *}$ \\
\hline & {$[0.55]$} & {$[0.40]$} & {$[0.86]$} & {$[0.58]$} & {$[1.04]$} & {$[2.50]$} \\
\hline NONINT & 0.01 & 0.02 & 0.01 & -0.00 & 0.01 & 0.29 \\
\hline & {$[0.02]$} & {$[0.01]$} & {$[0.12]$} & {$[0.01]$} & {$[0.03]$} & {$[0.35]$} \\
\hline CAP & $\begin{array}{l}-0.04 \\
{[0.03]}\end{array}$ & $\begin{array}{l}-0.05 \\
{[0.04]}\end{array}$ & $\begin{array}{l}-0.09 \\
{[0.06]}\end{array}$ & $\begin{array}{c}0.01 \\
{[0.03]}\end{array}$ & $\begin{array}{c}0.06 \\
{[0.05]}\end{array}$ & $\begin{array}{l}-0.20 \\
{[0.24]}\end{array}$ \\
\hline$\Delta \mathrm{GDP} * \mathrm{DB}$ & $\begin{array}{l}-0.45^{* * *} \\
{[0.15]}\end{array}$ & $\begin{array}{l}-0.33 \\
{[0.23]}\end{array}$ & $\begin{array}{l}-0.57^{* * *} \\
{[0.15]}\end{array}$ & $\begin{array}{l}-0.37^{* *} \\
{[0.16]}\end{array}$ & $\begin{array}{l}-0.40^{* * *} \\
{[0.15]}\end{array}$ & $\begin{array}{l}-1.06^{* *} \\
{[0.52]}\end{array}$ \\
\hline ELECT $*$ DB & $\begin{array}{c}-2.20^{* *} \\
{[0.89]}\end{array}$ & $\begin{array}{l}-2.06 \\
{[1.46]}\end{array}$ & $\begin{array}{l}-2.20^{* *} \\
{[0.99]}\end{array}$ & $\begin{array}{l}4.77^{* * *} \\
{[1.59]}\end{array}$ & $\begin{array}{l}3.44^{* *} \\
{[1.49]}\end{array}$ & $\begin{array}{l}9.09^{* *} \\
{[3.55]}\end{array}$ \\
\hline Bank f.e. & YES & YES & YES & YES & YES & YES \\
\hline Country-year f.e. & YES & YES & YES & YES & YES & YES \\
\hline Observations & 33,787 & 26,855 & 4,073 & 6,414 & 3,073 & 577 \\
\hline N. of countries & 13 & 13 & 13 & 14 & 14 & 11 \\
\hline
\end{tabular}

The sample is split based the geographical divide between Western Europe and Central-Eastern Europe. The regression is run within separate size classes: (i) the whole sample (columns 1-3); (ii) the smaller DB's size class (columns 4-6), which includes banks in the percentiles 22-90 by total assets; (iii) the larger DBs' size class (columns 7-9), which includes banks above the 90th percentile (see Section 3.1 for details). The dependent variable $\Delta$ LOANS measures the change in total loans in year $t$ as a share of total assets in year $t-1$. LTA is the logarithm of lagged total assets in EUR thousands. NONINT is the lagged share of non-interest income over average total assets (i.e. the average of total assets at the beginning of the year and at the year's end). CAP is the lagged share of total equity over total assets. $\triangle$ GDP is the GDP growth rate by country and year. ELECT is the share of the year $t$ that falls within the twelve months prior to a national election in country $c$. DB is a dummy variable that takes the value of one for development banks. The reference period is 2002-2015. Robust standard errors in brackets.

Significance levels: ${ }^{*} p<0.1,{ }^{* *} p<0.05,{ }^{* * *} p<0.01$ 